\title{
History on the biological nitrogen fixation research in graminaceous plants: special emphasis on the Brazilian experience
}

\author{
JOSÉ I. BALDANI and VERA L.D. BALDANI \\ Embrapa Agrobiologia, BR465, Km 07, 23851-970 Seropédica, Rio de Janeiro, Brasil \\ Manuscript received on December 27, 2004; accepted for publication on April 6, 2005; \\ presented by EuríPEDES MaLAVOLTA
}

\begin{abstract}
This review covers the history on Biological Nitrogen Fixation (BNF) in Graminaceous plants grown in Brazil, and describes research progress made over the last 40 years, most of which was coordinated by Johanna Döbereiner. One notable accomplishment during this period was the discovery of several nitrogen-fixing bacteria such as the rhizospheric (Beijerinckia fluminensis and Azotobacter paspali), associative (Azospirillum lipoferum, A. brasilense, A. amazonense) and the endophytic (Herbaspirillum seropedicae, H. rubrisubalbicans, Gluconacetobacter diazotrophicus, Burkholderia brasilensis and B. tropica). The role of these diazotrophs in association with grasses, mainly with cereal plants, has been studied and a lot of progress has been achieved in the ecological, physiological, biochemical, and genetic aspects. The mechanisms of colonization and infection of the plant tissues are better understood, and the BNF contribution to the soil/plant system has been determined. Inoculation studies with diazotrophs showed that endophytic bacteria have a much higher BNF contribution potential than associative diazotrophs. In addition, it was found that the plant genotype influences the plant/bacteria association. Recent data suggest that more studies should be conducted on the endophytic association to strengthen the BNF potential. The ongoing genome sequencing programs: RIOGENE (Gluconacetobacter diazotrophicus) and GENOPAR (Herbaspirillum seropedicae) reflect the commitment to the BNF study in Brazil and should allow the country to continue in the forefront of research related to the BNF process in Graminaceous plants.
\end{abstract}

Key words: bacterial endophytes, diazotrophs, semi-solid $\mathrm{N}$-free medium, inoculation, cereals, grass plants.

\section{INTRODUCTION}

Research on BNF with grasses in Brazil was initiated by Johanna Döbereiner when she joined the research team at the National Center of Education and Agricultural Research of the Ministry of Agriculture, located at $\mathrm{Km} 47$ in the fifties. The first studies were

Dedicated to the memory of Dr. Johanna Döbereiner by two of her disciples who learned through working with her that research could be done with simplicity, perseverance, honesty, ethics and sagacity.

Correspondence to: José Ivo Baldani

E-mail: ibaldani@cnpab.embrapa.br on the occurrence of Azotobacter in acid soils of the "Baixada fluminense" (Döbereiner 1953). These studies gained visibility with the discovery of two new nitrogen-fixing bacteria associated with the rhizosphere of some gramineous plants: Beijerinckia fluminensis with sugarcane (Döbereiner and Ruschel 1958) and Azotobacter paspali with Paspalum notatum cv. batatais (Döbereiner 1966). In the seventies, a significant advance in the area of BNF in grasses was the introduction of the acetylene reduction method. Almost at the same time, the semisolid $\mathrm{NFb}$ medium that replicated the oxygen level 
found in soil niches was developed to isolate microaerophilic nitrogen-fixing bacteria associated with plant roots. This medium allowed the isolation of two new species of Azospirillum: A. lipoferum and $A$. brasilense. This marked the beginning of BNF research in grasses in Brazil as well in other countries. The research concentrated on several areas of the interaction between plants and bacteria including the microorganisms themselves. A new species of Azospirillum named A. amazonense (Magalhães et al. 1983) was isolated and identified using semi-solid LGI medium, derived from modification of the $\mathrm{pH}$ and carbon source of $\mathrm{NFb}$ medium (Baldani et al. 1984).

Several lines of research focusing on agricultural applications were developed. Hormonal effects, nitrogen assimilation, biological nitrogen fixation and even negative responses were frequently observed (Boddey and Döbereiner 1982). During this period, other groups working on BNF with nonleguminous plants were established in Brazil. Currently, besides the Embrapa Agrobiologia (Km 47) team there is groups in the States of Paraná, Rio Grande do Sul, Rio de Janeiro, Minas Gerais, Goiás, Ceará and Distrito Federal.

Research on the colonization of plant tissues by diazotrophic bacteria received a lot of attention from 1985 to 1990 and consequently some aspects of the plant-bacteria interaction began to be elucidated. Two new nitrogen-fixing bacteria able to colonize the interior of plant tissues were found: Herbaspirillum seropedicae, was isolated from plants of maize, sorghum and rice (Baldani et al. 1986a) and Gluconacetobacter diazotrophicus (synon. Acetobacter diazotrophicus) was isolated from sugarcane plants (Cavalcante and Döbereiner 1988).

This intimate interaction between macro and micro symbionts modified the concept known as associative and Döbereiner (1992a) introduced the endophyte concept to the field of BNF. From this point on, a new area within BNF was established which led to great advances in the understanding of physiology, ecology and genetics as well as in the interaction of the bacteria with the plant (Baldani et al. 1997a). New nitrogen-fixing bacteria were identified: Herbaspirillum rubrisubalbicans (Baldani et al. 1996), Herbaspirillum frisingense (Kirchhof et al. 2001), Azospirillum doebereinerae (Eckert et al. 2001), Gluconacetobacter johannae and Gluconacetobacter azotocaptans (Fuentes-Ramírez et al. 2001) and Burkholderia tropica (Reis et al. 2004).

This review aims to rescue the history of BNF studies with grasses in Brazil. These studies were mainly coordinated by Johanna Döbereiner and through her efforts this line of investigation was established in several parts of the World. In addition, it presents recent advances in the area.

\section{FREE-LIVING AND RHIZOSPHERIC}

NITROGEN-FIXING BACTERIA

\section{Azotobacter chroococcum}

These studies were mostly done between 1950 and 1970 when very little was known about the occurrence of these bacteria in tropical soils. In the first paper on the subject, Döbereiner (1953) observed a very frequent occurrence of Azotobacter chroococcum in 22 out of 27 acid soil samples collected in the "Baixada fluminense".

\section{Beijerinckia fluminensis}

The occurrence of nitrogen-fixing bacteria of the genus Beijerinckia was mentioned for the first time in Brazil and it was demonstrated that the size of the populations was related to vegetation, physical, and chemical characteristics of the soil (Döbereiner and Castro 1955). Additional studies on the occurrence of this genus in soil of several Brazilian States (Rio de Janeiro, São Paulo, Pernambuco and Paraná) led to the description of a new species of Beijerinckia named B. fluminensis (Döbereiner and Ruschel 1958). Analysis of 158 samples collected in different regions of Brazil showed that this species occurred predominantly in soils where sugarcane was cultivated (Döbereiner 1959a) and a direct influence of the plant on the development of the bacteria was suggested (Döbereiner 1959b). Addi- 
tional studies showed that roots as well as leaves and stems had a positive influence on Beijerinckia populations. This was influenced by the exudation of substances into the soil by the roots during rainfall (Döbereiner and Alvahydo 1959). Other studies involving the roots showed that the population of Beijerinckia was much more pronounced in the rhizoplane region (refers to the soil adherent to the root surface) than in the rhizosphere. In addition, it was shown that removal of the aerial part of the plant significantly reduced the population of bacteria in both the rhizoplane and rhizosphere regions (Döbereiner 1961). Rice plants grown in greenhouse and inoculated with Beijerinckia, showed the establishment of the bacteria as well as an increase in the yield (Döbereiner and Ruschel 1961). However, these types of experiments were not continued. Studies on the occurrence of Beijerinckia and Azotobacter were extended to other forage grasses and the results showed that Beijerinckia appears mainly in rhizoplane soil and Azotobacter in the rhizosphere (Ruschel and Döbereiner 1965).

In the 1970's, the introduction of acetylene reduction methodology stimulated further studies involving Beijerinckia and sugarcane. The measurement of the nitrogenase activity in roots of sugarcane showed that it was much higher than that observed in the rhizosphere and in soil between the plant rows. Beijerinckia indica was the most abundant bacterial species in both roots and soil samples (Döbereiner et al. 1972a). Quantification of BNF in sugarcane based on the extrapolation of the nitrogenase activity data indicated a contribution of $50 \mathrm{~kg} \mathrm{~N} / \mathrm{ha} /$ year to the soil/plant system (Döbereiner et al. 1973).

\section{Azotobacter paspali}

A gramineous plant that caught the attention of Johanna Döbereiner in the 1960's was Paspalum notatum, also known as forquilha or batatais grass. Today this grass still covers the campus of $\mathrm{Km} 47$ and lends the landscape a green color in the absence of added nitrogen fertilizer. A preliminary analysis on the occurrence of nitrogen-fixing bacteria with this grass showed that Beijerinckia and Azotobacter were the predominant bacteria in the rhizosphere, even with plants grown in acid soils (Ruschel and Döbereiner 1965). The use of silica gel plates, containing Winogradsky salts and calcium citrate as a carbon source, inoculated with rhizoplane or rhizosphere soil of Paspalum notatum, led to the isolation of a new species of Azotobacter, named Azotobacter paspali (Döbereiner 1966). This name was later changed to Azorhizophilus paspali (Thompson and Skerman 1981). The high frequency of this bacterium in the rhizoplane of $P$. notatum (75 out of 76 samples) and in two of three samples of P. plicatum, as well as its complete absence in 81 rhizoplane samples of other plants including 5 species of Paspalum, led to the suggestion that the observed specificity could represent an intermediate stage between the legume symbiosis and the non-symbiotic nitrogen fixation (Döbereiner 1970). Additional studies concerning the dependency of the bacteria on the plant showed that the bacteria developed much better on the rhizoplane (Machado and Döbereiner 1969). These authors also showed that root exudates stimulated growth of the bacterial population and that active substances present in these exudates tolerated high temperatures. One of the first evaluations on the BNF contribution of A. paspali to the plant was carried out by Donald Kass in 1970, and he detected a gain of $18 \mathrm{~kg} \mathrm{~N} / \mathrm{ha} / \mathrm{year}$ (Kass et al. 1971). At this time, the acetylene reduction activity (ARA) technique was being used and one addendum in the paper mentioned above indicated nitrogenase activities up to $25 \mathrm{nmols} \mathrm{C}_{2} \mathrm{H}_{4} / \mathrm{h} / \mathrm{g}$ dry root weight of batatais grass harvest in the field (Döbereiner and Campêlo 1971). Other studies confirmed the ARA observed for the cultivar batatais and also showed that it was almost zero for the pensacola cultivar (Döbereiner et al. 1972b). The highest activity was observed in the roots and rhizomes, located lower in the soil and was zero in the aerial parts. In addition, the authors observed that the bacteria formed microcolonies adjacent to roots of cv. batatais but not in the cv. pensacola. Extrapolation of the ARA data to BNF suggested a contribution of up to $50 \mathrm{~kg}$ 
N/ha/year (Döbereiner et al. 1973). BNF in cv. batatais was confirmed by the ${ }^{15} \mathrm{~N}_{2}$ technique with the incorporation of ${ }^{15} \mathrm{~N}$ into the plant tissues (DePolli et al. 1977). Later, Boddey et al. (1983) used the ${ }^{15} \mathrm{~N}$ dilution technique and demonstrated a BNF contribution of $20 \mathrm{~kg} \mathrm{~N} / \mathrm{ha} /$ year in plants grown under field conditions.

\section{Derxia spp}

Other nitrogen-fixing bacteria studied by Dr. Johanna Döbereiner's group in the 1960's belonged to the genus Derxia, represented by the species $D$. gummosa and D. indica. A preliminary study on the occurrence of D. gummosa in soils of Rio de Janeiro State, led to the isolation of this bacterium from 20 rhizosphere soil samples collected from different forage grasses (Döbereiner 1968). A more complete evaluation on the occurrence of Derxia in 100 soil samples from 4 Brazilian States (SP, RJ, PA and PE), cultivated mainly with grasses, showed its occurrence in $36 \%$ of root samples collected in RJ and PA, but not from other States represented mostly by samples from very dry regions (Campêlo and Döbereiner 1970). A unique experiment on the inoculation of Azotobacter vinelandii, Azotobacter paspali, Derxia sp. and Beijerinckia indica in Pennisetum purpureum plants, grown in greenhouse, was conducted by Souto and Döbereiner (1967). They observed a small but significant increase due to inoculation of the first three bacteria, however these bacteria did not colonize the rhizosphere. On the other hand, B. indica significantly increased the dry weight and total $\mathrm{N}$ of the plant and also colonized the rhizosphere. Unfortunately, these grass inoculation studies were not continued.

\section{Paenebacillus azotofixans}

Dr. Johanna Döbereiner also made an initial contribution to the study of the nitrogen-fixing bacterium Paenebacillus azotofixans (formerly Bacillus azotofixans) (Seldin et al. 1984), characterized by Dr. Elisa Gastão da Cunha Penido's group in the Microbial Genetic Laboratory of the Microbiology
Institute, Universidade Federal do Rio de Janeiro. Nowadays, Dr. Lucy Seldin's group is continuing the study of this Gram positive diazotroph. It has been demonstrated that $P$. azotofixans is genetically diverse and that there are a predominance of certain genotypes of $P$. azotofixans in the rhizosphere of grasses such as wheat and sugarcane (Rosado et al. 1998). A "rhizosphere effect" promoted by the wheat rhizosphere was also demonstrated (Rosado et al. 1996). A significant difference among the populations of $P$. azotofixans isolated from rhizoplane, rhizosphere and soil of maize variety commonly cultivated in Brazil has been observed. In addition, it has been shown that the soil type was responsible for this diversity (Seldin et al. 1998). These studies led to the isolation and description of a new species of Paenibacillus named P. brasilensis (von der Weid et al. 2002).

\section{ASSOCIATIVE NITROGEN-FIXING BACTERIA}

Semi-solid Medium and Discovery of Spirillum

The studies on associative bacteria began with the use of the acetylene reduction method to measure the capacity of gramineous plants to fix nitrogen in association with diazotrophs. The results showed high nitrogenase activity rates (ARA), however there was no direct relation to the nitrogen-fixing bacteria known at that time. During a talk at the International Conference on the Global Impact of the Applied Microbiology, held in São Paulo, 1973, nitrogenfree semi-solid medium was mentioned for the first time. This medium, containing starch or glycerol as a carbon source and calcium carbonate, when inoculated with small pieces of washed roots from gramineous plants gave rise to the development of an abundant pellicle with high nitrogenase activity. However, it was not possible to isolate and identify the predominant bacteria due to the difficulties in growing the organisms on plates containing nitrogen-free medium, even under low oxygen levels (Döbereiner 1973). During the first International Congress on BNF, held in Pullman, WA, USA, 1974, it was demonstrated that Spirillum lipoferum 
was the main nitrogen-fixing microorganism associated with the roots of the forage grass Digitaria decumbens (Döbereiner and Day 1975). In addition, the authors suggested that this bacterium was responsible for the high ARA rates detected. Changing the carbon source of the above-mentioned semisolid medium to sodium malate led to the isolation of this microaerophilic bacterium from roots of several gramineous plants. Later studies on the physiology of S. lipoferum showed that growth was $\mathrm{pH}$ dependent (best at pH 6.8 to 7.8). The optimum growth temperature under nitrogen-fixing conditions was between 32 and $40^{\circ} \mathrm{C}$. Although growth was aerobic, this organism was sensitive to oxygen and the best carbon sources were organic acids (Day and Döbereiner 1976). Studies on the localization of $S$. lipoferum in roots of $D$. decumbens, using the tetrazolium reduction technique, showed that the bacteria were mostly found in the inner cortex layer. This led to the suggestion that $S$. lipoferum was an intermediate between bacteria involved in the rhizospheric association and the legume symbiosis (Döbereiner and Day 1975).

\section{BNF Grass Potential Measurements by ARA}

After the discovery mentioned above, studies were carried out to evaluate the BNF potential of several forage grasses. In addition, it was observed that there were a few problems in applying the acetylene reduction technique to samples harvested directly from the field. A lag phase was detected during the measurement of the nitrogenase activity when extracted roots were used but not when the intact soil/plant system was evaluated. The strategy used to solve this problem was to maintain the root samples in flasks containing water and then substitute it with nitrogen gas in the laboratory. The flasks were incubated overnight at a low oxygen level before the injection of $10 \%$ of acetylene (Abrantes et al. 1976a). The use of this technique to evaluate the BNF potential of several forage grasses (Panicum maximum, Pennisetum purpureum, Brachiaria mutica, Digitaria decumbens, Cynodon dactylon and Melinis minutiflora) gave rates of 239 to $750 \mathrm{nmols}$
$\mathrm{C}_{2} \mathrm{H}_{4} / \mathrm{h} / \mathrm{g}$ of roots, which varied with the season and stage of plant development (Day et al. 1975). Soil temperature (Abrantes et al. 1976b) and the level of ammonia in the soil (Neves et al. 1976) also interfered with the nitrogenase activity. Due to the potential of BNF in grasses, the studies were directed towards plants of higher agricultural and economical importance such as cereals. Values of ARA around $10,000 \mathrm{nmols} \mathrm{C}_{2} \mathrm{H}_{4} / \mathrm{h} / \mathrm{g}$ dry roots were detected in maize plants grown in pots containing very wet soils and under high light intensity (Dommergues et al. 1973). At that time, the authors suggested that anaerobic nitrogen-fixing bacteria were the responsible for the activity. In 1975, von Bülow and Döbereiner published a study on the BNF potential of 276 S1 lines of maize. After an ARA pre-screening, 17 lines were tested under field conditions. The best lines continued to show high ARA values (between 2,000 and 7,000 nmols $\mathrm{C}_{2} \mathrm{H}_{4} / \mathrm{h} / \mathrm{g}$ roots) compared to $313 \mathrm{nmols} \mathrm{C}_{2} \mathrm{H}_{4} / \mathrm{h} / \mathrm{g}$ roots in the original cultivar. The authors verified the higher ARA activity during the flowering stage of maize and were able to isolate $S$. lipoferum even after surface sterilization of the roots with different agents (alcohol, chlorinated water, and hydrogen peroxide). They suggested that the association between S. lipoferum and the roots was located within the root tissues, since the very high ARA could not be explained by a simple causal association at the rhizosphere level. Based on the differences among genotypes, it was suggested that genetic studies on cereals that are able to associate with diazotrophs should be initiated on a species other than maize since maize breeding programs were mostly directed toward an $\mathrm{N}$ fertilizer response. Therefore, the characteristics that favored the association with nitrogen fixing bacteria were eliminated in this plant (Döbereiner 1976).

\section{NFb Medium ANd Description of}

\section{Azospirillum GENUS}

At the end of 1975, the semi-solid medium developed for the isolation of Spirillum species was officially named $\mathrm{NFb}$ ( $\mathrm{N}$ stands for new and $\mathrm{Fb}$ for Fábio Pedrosa). This medium was used to study the 
occurrence of S. lipoferum in several plants grown in tropical and temperate regions of Brazil and the USA (Döbereiner et al. 1976). The results showed that the $S$. lipoferum was very common in soil and in the roots of plants grown in tropical regions (Brazil and several African countries). Forage grasses and cereals always had a large bacterial population. Despite its lower occurrence, S. lipoferum was also isolated from plants grown under non-tropical conditions in the USA and Southern Brazil. A soil pH, between 5.5 and 7.0, favored the occurrence of the bacteria (Döbereiner et al. 1976). Preliminary field inoculation experiments carried out in Madison, Wisconsin, USA showed the establishment of the bacteria in the roots of the plants. However, at that time the S. lipoferum inoculation practice in tropical regions did not offer great prospects because of the wide distribution of the bacteria in tropical soils.

Advances in physiology and biochemistry suggested that other aspects should be studied. It was suggested that inoculation should only be done in the presence of low doses of nitrogen fertilizers to prevent inhibition/repression of the BNF process and to also lessen the environmental risks caused by the nitrogen fertilizer excess (Döbereiner 1977a). During an International symposium dealing with the application of genetic engineering to the field of nitrogen fixation, several aspects of the plant/bacteria interaction were discussed concerning the possibility of increasing the BNF association in grass plants (Döbereiner 1977b). At the meeting an interesting comment was made by Dr. Döbereiner. She said that the international scientific community did not carefully read the papers published on BNF in grasses therefore leading to a race to find S. lipoferum strains and maize lines to be used in agriculture. Although the potential of BNF in grasses was already demonstrated, the studies indicated that the best strategy to maximize BNF was through plant breeding programs (Döbereiner 1977c). Several studies carried out at that time showed that the plant genotype played an important role in the BNF process since there were highly significant differences in the nitrogenase activity observed among maize (von Bülow and Döbereiner 1975) and wheat cultivars (Nery et al. 1977). A highly significant negative correlation was observed between nitrogenase $\left(\mathrm{N}_{2}\right.$-ase) in the roots and nitrate reductase (NR) in the leaves with maize lines UR-I selected for high and low BNF. The results suggested that breeding programs focusing on BNF should also include studies on NR to select genotypes that gain from both $\mathrm{N}$ sources (Baldani et al. 1979).

\section{The ARA Method AND ITs Role IN THE BNF IN GRASS}

Due to its high impact on the study of BNF in grasses, the ARA method was the subject of discussion by the scientific community. The main topic referred to the use of isolated roots to measure the potential of BNF in different cereal genotypes. Multiplication of bacteria during the incubation of roots at low oxygen levels was the main criticism. In contrast to legumes, nitrogenase activity was detected only after incubation of the roots for 10 to 16 hours at low oxygen tension. This lag phase could, however, be reduced when carbonate was added to the roots (Baldani et al. 1978). A positive correlation between the nitrogenase activity produced by pieces of maize and Digitaria roots pressed into semi-solid $\mathrm{NFb}$ medium and by isolated roots of the same plants was demonstrated by Döbereiner and collaborators (Döbereiner 1978). This suggested that Spirillum was the main microorganism responsible for the ARA in these plants. Studies on BNF in 5 tropical forage grasses using isolated roots showed that the methodology underestimated the ARA values in comparison to those detected using the intact soil/plant system, although both techniques showed a significant correlation (Souto and Döbereiner 1984).

\section{Physiological and Biochemistry Studies}

Several physiological and biochemistry studies were conducted to gain a better understanding of the role played by Spirillum lipoferum in the association with grass plants. These studies confirmed observations that the bacteria were sensitive to high levels of oxy- 
gen and that the optimal $\mathrm{pH}$ for growth was between 6.8 and 7.0 and the optimal incubation temperature was between 32 and $36^{\circ} \mathrm{C}$. In addition, it was found that organic acids were the preferred carbon sources. Therefore, malic acid was the carbon source incorporated in the semi-solid NFb medium used to grow and isolate Spirillum lipoferum (Neyra and Döbereiner 1977). Another characteristic of the bacteria discovered at that time was the ability of some strains to participate in several steps of the nitrogen cycle in nature. The most surprising aspect was the ability to carry out denitrification since nitrogen-fixing bacteria were not known to carry out this process at that time (Neyra et al. 1977). Based on physiological and biochemical characteristics, three groups of bacteria were identified: Group I-no biotin requirement and the ability to use glucose as carbon source for growth and nitrogen fixation; Group II - a biotin requirement and glucose utilization; Group III - similar to Group I, except that it was able to reduce $\mathrm{NO}_{2}$ - to $\mathrm{N}_{2}$ (Sampaio et al. 1978).

A. lipoferum and A. brasilense species - Later studies, based on DNA:DNA homology, led to the creation of a new genus called Azospirillum with two species: Azospirillum lipoferum (synon. of Spirillum lipoferum) and Azospirillum brasilense (Tarrand et al. 1978). Serological studies showed that fluorescent antibodies could be used to differentiate the two species, however 3 subgroups were formed within A. brasilense (De-Polli et al. 1980).

A. amazonense species - A new species of Azospirillum, named A. amazonense, was later described (Magalhães et al. 1983). The species was isolated from forage grasses grown in the Amazon and in the State of Rio de Janeiro and later from rice, maize and sorghum plants grown in Seropédica, Rio de Janeiro (Baldani 1984). Its broad ecological distribution was later confirmed through the detection of large numbers of the bacteria in other grasses such as sugarcane (Baldani et al. 1999). The main characteristics that differentiate it from other species are the ability to use sucrose as carbon source, a smaller cell diameter and an inability to tolerate alkaline $\mathrm{pHs}$ (Magalhães et al. 1983).
Other Azospirillum species - During the last two decades, other species of Azospirillum have been described: A. halopraeferens associated with Kallar grass grown in saline soils of Pakistan (Reinhold et al. 1987), A. irakense associated with rice plants grown in Iraq (Khammas et al. 1989), $A$. largimobile (the original name largomobile was orthographically incorrect) isolated from a water sample collected from a lake in Australia (Dekhil et al. 1997) and A. doebereinerae associated with Pennisetun plants grown in Germany (Eckert et al. 2001). Very few studies have been carried out with these Azospirillum species, except for A. irakense where pectinolytic activity was observed (Vande Broek and Vanderleyden 1995).

\section{Physiological and Biochemical Studies}

Evaluation of the nitrogen fixation mechanisms in these Azospirillum species showed that inhibition of nitrogenase activity by nitrate was dependent on the reduction of nitrate (Magalhães et al. 1978). In addition, the authors showed that under aerobic conditions, where nitrogenase is inhibited by oxygen, nitrate could be used as a nitrogen source for growth. An elegant schema presented by Döbereiner (1979) illustrates how oxygen and mineral nitrogen sources interfere with the BNF process in Azospirillum. It was observed that when the oxygen supply to the bacterial site exceeds its consumption, $\mathrm{NH}_{3}$, $\mathrm{NO}_{3}$ and $\mathrm{NO}_{2}$ are assimilated at maximal rates, but there is no BNF. In contrast, when the consumption of oxygen corresponds exactly to the amount transported to the site, the conditions are optimum for nitrogenase synthesis by the bacteria and in the case where mineral $\mathrm{N}$ sources $\left(\mathrm{NH}_{3}, \mathrm{NO}_{3}\right.$ and $\left.\mathrm{NO}_{2}\right)$ are not available, atmospheric $\mathrm{N}_{2}$ is used as nitrogen source. If oxygen is removed, respiration is interrupted, and ATP is not generated. This, in turn, results in the cessation of nitrogen fixation. On the other hand, nitrate can be substituted by oxygen. In this case, the product of respiration (nitrite) is excluded from the cells. Nitrogen fixation is not inhibited and the process becomes dependent on nitrate as demonstrated by Scott et al. (1979). A 
study on the inorganic $\mathrm{N}$ transformation processes in presence of Azospirillum, showed that the bacteria participate in all steps except in the nitrification process (Bothe et al. 1981). The authors verified that nitrogenase activity dependent on nitrate occurs only during 3 to 4 hours until the assimilatory enzymes involved in the reduction of nitrate are synthesized. During this period, nitrite accumulates and the nitrogenase is inhibited when the concentration reaches about $1 \mathrm{mM}$. Additional studies on the tolerance of Azospirillum to oxygen carried out in a fermenter, showed that the level of tolerance is dependent on the age of the culture, optical density and rate of shaking (Volpon et al. 1981). Oxygen tolerance is greater in A. lipoferum and occurred when the concentration of lactate and glucose in the medium decreases to less than 0.5\% (Stephan et al. 1981, Volpon et al 1981). More information on the physiology and biochemistry of these 3 species of Azospirillum can be found in a book written by Döbereiner and Pedrosa (1987).

\section{Ecological and Colonization Studies}

Several studies were carried out on the colonization process and the establishment of Azospirillum in different grasses. One of the first studies made use of the tetrazolium reduction method (Patriquin and Döbereiner 1978). The authors observed bacterial colonization of the cortex tissues and the inner central region of maize roots and other forage grasses. Further studies, using maize plants grown in the field confirmed the endorhizospheric nature of the association with bacteria present in the central cylinder of the roots as well as in the xylem vessels in colm nodal regions (Magalhães et al. 1979). The highest frequency of colonization occurred during the grain filling stage $\left(10^{5}\right.$ to $10^{7}$ cells/g root tissue) when the nitrogenase activity is usually much higher. Although this methodology and the results have been subjected to criticism, the intercellular colonization of maize and wheat plants by Azospirillum has been confirmed more recently by molecular techniques (Assmus et al. 1995).

A survey on the occurrence of the Azospirillum species known up to 1980 , showed that there was a certain host plant specificity in the colonization of $\mathrm{C}_{3}$ and $\mathrm{C}_{4}$ plants by Azospirillum (Baldani and Döbereiner 1980). The authors observed that maize plants were preferentially colonized by A. lipoferum while wheat and rice were colonized by A. brasilense. These results were later confirmed for other forage grasses with $\mathrm{C}_{3}$ and $\mathrm{C}_{4}$ photosynthetic pathways and in addition showed a higher occurrence of denitrifying strains colonizing the interior of roots (Baldani et al. 1981). Another interesting characteristic of the Azospirillum that colonized the interior of roots of cereals was the high frequency of isolates with a tolerance for up to $20 \mathrm{ppm}$ of streptomycin as compared to strains isolated from the soil or rhizosphere (Döbereiner and Baldani 1979). This discovery led to a suggestion that the plants developed a new mechanism to select root-colonizing bacteria (Döbereiner 1979). Further studies showed that liming stimulated the production of streptomycin in the rhizoplane of several gramineous plants (Baldani et al. 1982).

In the International Workshop on Associative $\mathrm{N}_{2}$-Fixation, held in 1979, in Piracicaba, SP, Brazil a new term "diazotrophic biocoenosis" was introduced to describe the association of plants of the family Gramineae (renamed Poacea) with nitrogen-fixing bacteria (De-Polli and Döbereiner 1980). Three more specific terms were also considered; "rhizocoenosis" (roots), "caulocoenosis" (stems) and "phylocoenosis" (leaves). However, these new terms were not used by the scientists working in this area, therefore the term "associative" continued to be used to describe the association of diazotrophic bacteria, mainly Azospirillum, with non-leguminous plants. Later 1992a, Döbereiner introduced (as discussed below) the term endophyte, to define bacteria able to colonize internal plant tissues. A group coordinated by Dr. Fátima Moreira (Universidade Federal de Lavras, UFLA, Minas Gerais) detected a large population of this species in plants of the Orchidaceae family as well as in species of other plants (Lange and Moreira 2002). Further studies carried out by her group on the ecology of Azospirillum in 
heavy metal contaminated area as well as in bauxite mining reclamation area showed that the population of Azospirillum was similar to the one detected in non-contaminated agricultural ecosystems, but was drastically reduced in the bauxite mining area. On the other hand, the use of several gramineous species in this area promoted a qualitative and quantitative increase in diazotrophic bacteria populations with values higher than those observed for reference areas (Melloni et al. 2004). The analysis of the nitrogenfixing bacteria present in these areas showed a high diversity of the diazotrophs including Azospirillum and Herbaspirillum species as well as other unidentified ones (Nóbrega et al. 2004).

\section{INOCULATION RESPONSES}

The advances generated in the 70's led several researchers to evaluate the effect of Azospirillum inoculation on gramineous plants. The results although inconsistent, indicated a potential contribution by the BNF process of around $40 \%$ of the nitrogen requirement based on observations by groups in Brazil and Israel (Boddey and Döbereiner 1982). However, the debate about the principal role played by bacteria in association with plants still remained. Several authors as summarized by Patriquin et al. (1983) demonstrated hormonal effects, biological nitrogen fixation and interference in other processes of the nitrogen assimilation.

Field wheat inoculation experiments with Azospirillum strains isolated from sterilized roots of wheat (Sp 245, Sp 107 st), showed a consistent increase in total plant $\mathrm{N}$ however, this was not the case for the heterologous strain Sp 7 (Baldani et al. 1983). High correlation $(r=0.92)$ was observed between $\mathrm{N}$ accumulation and the number of Azospirillum present in sterilized roots but there was not a significant correlation with the number of Azospirillum detected in washed roots. A positive inoculation effect on maize plants was observed when homologous strains of Azospirillum were compared with strains isolated from other plants (Freitas et al. 1982). At this time, studies were initiated to evaluate the location of different strains of Azospirillum (ho- mologous and heterologous) in wheat and sorghum plants grown in the field (Baldani et al. 1986b). The authors observed that homologous strains were preferentially located in the interior of roots of wheat plants (Sp245 and Sp107) and sorghum (Sp S82) while the heterologous strains ( $\mathrm{Sp} 7$ and $\mathrm{Cd}$ ) were found on the root surface.

Other studies confirmed the inoculation effect of Azospirillum strains on wheat plants grown in the field. It was demonstrated that the observed effect, mainly with homologous strain Sp 245, was not due to BNF but to an increase in the nitrate reductase (NR) activity of the bacteria in the roots (Boddey et al. 1986). The role of bacterial NR in the plant $\mathrm{N}$ metabolism was confirmed by inoculating wheat plants grown under gnotobiotic conditions with nitrate reductase negative mutants (Ferreira et al. 1987). Besides BNF and its role in the plant metabolism, inoculation with Azospirillum can stimulate plant growth through production of auxins, gibberellins and citokinins (Hartmann and Zimmer 1994). Some countries, not including Brazil, are commercially producing inoculants based on Azospirillum (Baldani et al. 1999). However, practical application still represents an incognito due to inconsistent results.

\section{Genetics Studies}

Reviews published in the last decade have made a lote of advances in the physiology, biochemistry and genetics of the Azospirillum species. In addition, the role of these bacteria in the interaction with gramineae plants and other non-legume plants has been confirmed (Vande Broek and Vanderleyden 1995, Bashan and Holguin 1997, Steenhoudt and Vanderleyden 2000). In Brazil, studies on the organization and regulation of the nif genes in the BNF process of the genus Azospirillum have been conducted by groups led by Dr. Fábio de Oliveira Pedrosa, Universidade Federal do Paraná (UFPR) and Dr. Irene Schrank, Universidade Federal do Rio Grande do Sul (UFRGS).

Dr. Pedrosa's group played an important role in research involving the regulation of BNF in 
Azospirillum brasilense. They isolated the first mutants with mutations in the regulatory genes nifA and $n t r C$ that code for the transcription activating proteins NifA and NtrC (Pedrosa and Yates 1984). These mutants aided the isolation of the ntrBntrC operon of $A$. brasilense by genetic complementation of nifA, nifB genes (Knopik et al. 1991, Machado et al. 1995). This work led to an intensified effort at the molecular level in order to understand the structural organization and regulation of the nif genes of this endophytic diazotrophic bacterium. The work on Azospirillum brasilense was initially centered on the isolation and characterization of regulatory mutants able to constitutively fix nitrogen in presence of $\mathrm{NH}_{4^{+}}$(Machado et al. 1991). These mutants were also able to excrete ammonia, the product of the nitrogen fixation process (Machado et al. 1991, Vitorino et al. 2001). The group has also dedicated considerable effort on studying the regulation of the nitrogen fixation process in A. brasilense. This regulation did not depend on the transcription activating proteins NtrC, NifA and the Sigma RNA polymerize factor, $\sigma^{\mathrm{N}}$. The nifA promoter, which does not show typical structural motifs of the promoters of promoter dependent proteins, was characterized as a typical $\sigma^{70}$ promoter. Studies on chromosomal nifA::lacZ fusions and plasmid borne fusions showed that nifA expression of $A$. brasilense is repressed by ammonium, the principal effector. Low oxygen tension activates while high oxygen tension represses. Other results showed that the repression of nifA expression reaches its maximum level as a result of a synergistic effect between ammonium and oxygen (Fadel-Picheth et al. 1999).

Dr. Fabio's group recently described NtrX $\mathrm{NtrY}$ as a potential regulator involved in nitrate metabolism in A. brasilense, however it does not participate in regulation of nitrogen fixation (Ishida et al. 2002). The role of $G \ln Z$ in the reactivation of dinitrogenase reductase under ammoniumlimiting conditions as well as the requirement of the PII protein to turn the enzyme off were also important to understanding the control of nitrogenase activity in A. brasilense (Klassen et al. 2001). In addition, the group determined the genomic structure using pulse-field eletrophoresis of the Azospirillum genus (Martin-Didonet et al. 2000) and also constructed gene fusions using $g f p$ and $g u s A$ reporter genes to monitor the plant/bacteria interaction (Ramos et al. 2002).

The studies coordinated by Dr. Schrank's group, Universidade Federal do Rio Grande do Sul/ UFRGS, initially concentrated on the genes that encode the nitrogenase subunits in the A. brasilense species (Schrank et al. 1987). The nitrogenase structural gene operon was completely sequenced and the gene organization was found to be nifHDKorf1Y (Passaglia et al. 1991). Furthermore, the operons orf2nifusvorf4 (Frazzon and Schrank 1998), nifENXorf3orf5fdxAnifQ (Potrich et al. 2001a) and fixABCX (Irene Shrank, personal communication) were characterized. The group also studied the regulation of the nif operon in A. brasilense. The sequence of the structural gene operon showed the presence of two overlapping UASs, a unique characteristic among all of the nif operons so far analyzed. In vivo assays showed that one UAS (UAS2) has higher activity than UAS1 and that NifA binds to the two muted promoters (Passaglia et al. 1995). Antibodies specific for $A$. brasilense NifA were also produced (Passaglia et al. 1998). It was demonstrated that the binding activity of the purified NifA protein is not altered even when it is inactivated (presence of oxygen) and it is also able to bind to the nifH gene promoter when the UASs are mutated (Passaglia et al. 1995). Two mutants with higher nitrogen fixation activity than the wild type were obtained during selection of the nif genes (Araújo et al. 1988). One mutant was characterized and it was shown that the gene (ORF280) containing the mutation encodes a predicted gene product that is homologous to proteins involved in stress (Revers et al. 2000). More recently Dr. Schrank's group initiated studies with A. amazonense to determine similarities and difference between this species and A. brasilense. Using PCR primers designed for nif or fix gene sequences of $A$. brasilense, products from A. amazonense ge- 
nomic DNA were isolated and sequenced from the nifHDK, nifUSV, nifENX and fixABC operons. Southern blot hybridization was also carried out using different operon probes against the genome of A. amazonense. These results suggest that the nif/fix operons are present in A. amazonense, however they exhibited different patterns of restriction enzyme cleavage. The nitrogenase structural genes, which are conserved among different bacterial genera, are also different in A. brasilense and A. amazonense. A conserved region was found in the nifD gene, but the intergenic region of nifH-D and the promoter region of nifH were quite different. Also, genes involved in the regulation of nitrogen fixation such as those that encode NifA and PII protein were isolated and partially sequenced (Potrich et al. 2001b).

\section{ENDOPHYTIC BACTERIA}

\section{ENDOPHYTIC DEFINITION}

The term endophyte was first introduced to the area of nitrogen fixation research associated with Graminaceous plants by Döbereiner (1992a, b). The term was defined by De Bary (1866 cited by Stone 1986) and refers to mycotic flora that inhabits the interior of plant tissues. The term was then applied to bacteria and was the subject of several conceptual definitions. In general, the term includes all microorganisms that are able to colonize, during some portion of their life cycle, the inner tissues of plants without causing any apparent damage to the host (Petrini 1991). Herbaspirillum, Gluconacetobacter and Burkholderia are the three endophytic nitrogen-fixing bacteria studied by the Brazilian groups presented below.

\section{Herbaspirillum seropedicae}

The first nitrogen-fixing bacterium with endophytic characteristics was isolated in 1984 from the rhizosphere, washed roots and surface sterilized roots of maize, sorghum and rice plants and was first named Azospirillum seropedicae (Baldani et al. 1984). Although this group of bacteria showed several mor- phological and physiological characteristics similar to the genus Azospirillum, DNA: DNA homology studies showed that they formed a new genus named Herbaspirillum, thus Azospirillum seropedicae was renamed Herbaspirillum seropedicae (Baldani et al. 1986a).

\section{Genetics Studies}

Not much progress was made until the beginning of the 90's when Dr. Fábio Pedrosa's group focused their attention on the organization and regulation of the nif genes in this species. They isolated the nifA, and nifB genes along with the ntrBntrC operon of $H$. seropedicae by genetic complementation of A. brasilense Nif minus mutants (Souza et al. 1991a, b, Pedrosa et al. 1997). The nitrogenase structural genes, other nif genes, and genes involved in the regulation of the nitrogen fixation of $H$. seropedicae were sequenced. The nif genes were found in two regions; region I contains the genes contiguous with nifA and nifB, while region II contains the nifHDKENXorflorf2orf3 operon (Machado et al. 1996, Klassen et al. 1999, Pedrosa et al. 2001). The nifQmodABC and fixXC genes are located $3 \mathrm{kbp}$ upstream (Klassen et al. 1999). The group studied the motif functions present in the promoter region of nifA in detail. Structurally, this region shows a very high complexity. It has two potential NtrC-binding sites, three NifA sites and one IHF (integration host factor) - binding site localized upstream of an $\sigma^{\mathrm{N}}$ type promoter $(-24 /-12)$ (Souza et al. 1991b, Wassem et al. 2000, 2002). In summarizing, the studies showed that $\mathrm{NtrC}$ and $\mathrm{RpoN}$ are essential for expression from the nifA promoter and that IHF positively modulates activation by $\mathrm{NtrC}$ and acts negatively for activation by NifA (Souza et al. 1991a, b, 1999, 2000, Wassem et al. 2000). In vivo and in vitro studies of the function and structure of the $H$. seropedicae NifA protein showed that this transcription activator responds to external signals such as $\mathrm{NH}_{4}$ and $\mathrm{O}_{2}$. The $\mathrm{N}$-terminal region of NifA is involved in auto regulation in response to the negative regulator $\mathrm{NH}_{4^{+}}$in concert with PII which is essential for activation of NifA in 
absence of $\mathrm{NH}_{4^{+}}$(Monteiro et al. 1999a, b). Dr. Pedrosa's group also demonstrated that the NifA protein of $H$. seropedicae, similar to those from the $\alpha$-Proteobacteria (including A. brasilense), is sensitive to oxygen. Besides, it requires Fe for in vivo activity and the interdomain region between the $\mathrm{C}$ terminal domain and the central domain is involved in oxygen sensitivity (Monteiro et al. 1999a, Souza et al. 1999). In addition, Dr. Pedrosa's group isolated and characterized the $g \ln B$ gene of $H$. seropedicae and determined the three-dimensional structure of the purified protein product, a transducer protein of the PII signal. This structure is similar to that of the GlnK of enterobacteriaceae and it has a role in the control of NifA activity (Benelli et al. 1997, 2001, 2002). The genes glnAntrBntrC were also sequenced by the group (GenBank accession number AF0828730) and constitutes a unique operon where transcription is initiated from two promoter sequences. One promoter is $\mathrm{sN}$ dependent and the other is $\sigma^{70}$ dependent and, both promoters are located upstream of $g \ln A$ (Persuhn et al. 2000). Two genes involved in the SOS repair system, $r e c A$ and $r e c X$ of $H$. seropedicae were isolated, sequenced and their functions are being determined (Steffens et al. 1993).

\section{Genomic Studies}

The sequence and annotation of the $H$. seropedicae genome has almost been completed by the GENOPAR Consortium of Parana State, coordinated by Dr. Pedrosa. The consortium involves a net of 16 laboratories from Paraná, three from Santa Catarina, two from Rio de Janeiro and one from Rio Grande do Sul. The objective of the project is to gain an understanding of the overall metabolic pathways of $H$. seropedicae with a view towards increasing the efficiency of the plant/bacteria association.

\section{H. rubrisubalbicans}

Also in the 90's, a bacterium responsible for the mottled stripe disease in sugarcane was isolated. This strain belongs to the species Pseudomonas rubrisubalbicans and shows many characteristics similar to those of the genus Herbaspirillum (Döbereiner et al. 1990, Gillis et al. 1991). It was shown that it has the ability to fix atmospheric nitrogen and that it could also be reisolated from sugarcane leaves 60 days after artificial inoculation of the leaves (Pimentel et al. 1991). Additional physiological studies showed that this bacterium has some characteristics that are different from those of H. seropedicae (Baldani et al. 1992a). Based on this information, a complete study on this group of bacteria was carried out and culminated with the description of a new species named H. rubrisubalbicans (Baldani et al. 1996). The genus has recently been expanded with the description of a new species named $H$. frisingense, isolated from roots and leaves of forage grasses grown in Germany and Brazil (Kirchhof et al. 2001). A survey on the occurrence of this genus showed that the species $H$. seropedicae is found associated with several nonleguminous plants but not in soil in the absence of plants (Olivares et al. 1996). H. rubrisubalbicans has been isolated from many Brazilian sugarcane varieties with no symptoms of the mottled stripe disease (Döbereiner 1992b), however its ecological distribution is still unknown. Bacteria belonging to the genus Herbaspirillum were detected in wild and commercial rice varieties cultivated in Japan, however no relation with known species of Herbaspirillum could be found (Elbeltagy et al. 2001).

One aspect that was a strong consideration for inclusion of this genus in the endophytic group is its lower survival in soil (Baldani et al. 1992a). Olivares et al. (1996) verified the observation that the recovery of $H$. seropedicae and $H$. rubrisubalbicans strains inoculated into soil only occurred in the presence of the host plant. This was probably due to the release of growth promoter substances in the rhizosphere by the plant. However, Arcanjo et al. (2000) were unable to reisolate strains of Herbaspirillum from soil samples collected within sugarcane fields even when sugarcane micropropagated plants were used as the trapping host. Similarly, no Herbaspirillum strains could be isolated and analyzed us- 
ing the Immunocapture technique from soil samples collected between rows of sugarcane in the field (Santos et al., unpublished data).

\section{Colonization and Infection Studies}

The interaction of H. seropedicae and H. rubrisubalbicans strains with plants has been extensively studied through the inoculation of sugarcane and rice plants grown under sterile conditions followed by microscopic analysis. In rice plants, $H$. seropedicae has been found to colonize the intercellular spaces near the tip of young roots. Apparently, the bacteria move intercellularly to the cortex region, since the cortical cells are where large numbers of bacteria have been detected (Baldani et al. 1992b). More recent results, from studies with aluminum-tolerant rice cultivars grown under axenic and field conditions, confirmed observations that $H$. seropedicae colonizes the interior of roots and the aerial part of the plant (Gyaneshwar et al. 2002). Colm of sorghum plants artificially inoculated with H. rubrisubalbicans showed slight symptoms of the "red stripe" disease in the leaves suggesting an active translocation of the bacteria (Döbereiner et al. 1994). In contrast, no symptoms were observed with the inoculation of $H$. seropedicae strains. Further studies showed a very high rate of infection of the xylem vessels and the formation of a structure originating from the plant involving grumes of bacteria (James and Olivares 1998). In the case of sugarcane, it was observed that the bacteria enter the plant near the region of root emergence and invade the vascular tissues by colonizing the parenchymatic cells and methaxylem vessels (Olivares et al. 1995).

Most of the microscopic researches carried out in Brazil with these endophytic diazotrophic bacteria are now coordinated by Dr. Fábio Lopes Olivares (UENF University, Rio de Janeiro State). Besides the studies involving endophytic establishment in sugarcane by Herbaspirillum spp. using conventional microscopy (James et al. 1997, Olivares et al. 1997), cryotechnique approaches have opening insights for new ultrastructural aspects of the bacteria in free state and under endophytic interac- tion (Silva et al. 2003). Using cryofracture technique it was possible to conclude that the amount and the polymeric composition of the PHB granules changes depending on the physiological condition of the bacteria growing in the medium, based mainly on the status of Nitrogen and Carbon. Under endophytic interaction viewed by TEM after high pressure freezing followed by freezing substitution, Herbaspirillum spp. infected leaves as microcolonies into the lumem of the metaxylem vessel and as single cell/micro-colony at apoplast. In roots, $H$. seropedicae colonized cortex apoplast, adhered to plant cell wall (PCW), such as xylem vessels and inside apparently dead vascular parenchyma cells. Plant roots inoculated with the bacteria showed the bacteria associated with the intercellular root cortex. Cryotechniques were able to reveal altered aspects of all bacteria and PCW at adhesion sites and bacterial protrusions could be observed too. With great frequency, the bacteria were observed involved by abundant unknowing electron-dense material and many of vesicular structures coming from plant cell wall were also observed. All substances produced by PCW are clearly stimulated in response to bacterial presence. These bacterial compounds could stimulate the plant cell not only in relation to $\mathrm{N}_{2}$ fixing process but also in process involved other plant-growth promotion process (Silva et al. 2004).

\section{INOCULATION RESPONSE}

The potential of cereal plants to respond to inoculation with $H$. seropedicae strains has been evaluated by many experiments in the last 15 years. The initial results showed no positive response for sorghum (Pereira et al. 1988) and maize (Pereira and Baldani 1995). In the case of rice, inoculation promoted a yield increase equivalent to the treatment with $40 \mathrm{~kg}$ of N/ha (Pereira and Baldani 1995). However, large advances have been made in the last few years through a highly detailed study based on selection of Herbaspirillum strains grown in association with rice plants grown under gnotobiotic conditions (Baldani et al. 2000). It was observed that the response of the rice variety to inoculation 
was dependent on the strain used. In some cases, highly significant increases in phytomass accumulation were observed with the inoculation of some strains, whilst the opposite was observed for others (Baldani et al. 2000). Evaluation of these strains under greenhouse and field conditions also showed significant increases in yield, however this increase depended on the rice cultivar tested (Guimarães et al. 2000).

\section{Gluconacetobacter diazotrophicus}

The other diazotrophic bacterium with endophytic characteristics and object of intense research is Gluconacetobacter diazotrophicus (synon. Acetobacter diazotrophicus). The search for this bacterium was initiated with the observation that some sugarcane varieties could obtain around $60 \%$ of their nitrogen through biological nitrogen fixation (Lima et al. 1987). Initially, different semi-solid media were used. However, the medium containing $1 / 4$ of LGI salt supplemented with $250 \mathrm{~mL}$ of sugarcane juice and $25 \mathrm{~g}$ of crystal sugar was chosen because $G$. diazotrophicus formed a very thick yellow pellicle on the surface of the medium. This medium was suitable for the detection of bacteria in root and colm samples up to $10^{7}$ dilution (Cavalcante and Döbereiner 1988). Through knowledge acquired on the physiology of this organism, the authors modified the semi-solid medium, now named LGIP, and established as a rule the use of $10 \%$ crystal sugar with the $\mathrm{pH}$ adjusted to 5.5 using acetic acid. The medium was again modified by Reis et al. (1994) with the addition of sugarcane juice in the concentration of $0.5 \%$.

Based on morphological, physiological and biochemical characteristics of this group of bacteria, a new genus named Saccharobacter was created with a new species called $S$. nitrocaptans (Cavalcante and Döbereiner 1988). However, DNA: DNA and rRNA hybridization analysis showed that this group of bacteria belonged to an rRNA branch of Acetobacter with many characteristics similar to $A$. liquefaciens. Therefore, it was included in the genus Acetobacter with the creation of the species Acetobacter diazotrophicus, a unique nitrogenfixing bacterium of this genus (Gillis et al. 1989). Recently, this species was renamed Gluconacetobacter diazotrophicus based on the 16S rDNA sequence and the predominant type of ubiquinone produced (Yamada et al. 1997, 1998). Recently, two new nitrogen-fixing species of this genus were described: G. azotocaptans and G. johannae, with the last one in honor of Johanna Döbereiner (FuentesRamírez et al. 2001).

\section{ECOLOGICAL STUdiES}

G. diazotrophicus was initially isolated from roots and colms of sugarcane varieties grown in the Northeast (PE and AL) and Southeast (SP, MG) of Brazil (Cavalcante and Döbereiner 1988). It could not be detected in soil samples collected between sugarcane rows or in roots of 12 weed plants grown in sugarcane fields nor in grain of saccharine sorghum. However, it could be isolated from washed roots and aerial tissues of Pennisetum purpureum cv. cameroon plants (Döbereiner et al. 1988). Its occurrence was confirmed in other Brazilian sugarcane areas (Döbereiner et al. 1990) as well as in other countries that produce sugarcane such as Australia and USA (Baldani et al. 2002a).

Until quite recently, it was thought that $G$. diazotrophicus could only occur in plants that propagate vegetatively such as sugarcane, sweet potato (Paula et al. 1990, Döbereiner et al. 1993) and pineapple (Tapia-Hernandez et al. 2000). However, it was detected in plants propagated by seeds such as the grass Eleusine coracana (Loganathan et al. 1999) and in coffee (Fuentes-Ramirez et al. 2001), although these observations refer to the new species mentioned above, G. johannae and G. azotocaptans. G. diazotrophicus has already been detected in mealybugs that inhabit sugarcane fields (Ashbolt and Inkerman 1990) and in mycorriza spore fungi collected from sweet potato roots (Paula et al. 1991). Genetic diversity studies conducted on $G$. diazotrophicus strains isolated from sugarcane plants cultivated in Brazil and Mexico showed that diversity 
is very limited (Caballero-Mellado and MartinezRomero 1994). Studies from our laboratory with 45 strains isolated from sugarcane varieties, maintained for 30 years in a germoplasma bank and analyzed by the ITS/RFLP technique, also confirmed this low genetic diversity (Santos et al. 1999).

Other studies using ELISA, Immunocapture and PCR techniques have been conducted in an effort to detect $G$. diazotrophicus in soil samples and plant tissues. Using the ELISA technique, large populations of $G$. diazotrophicus were detected in different plant tissues of sugarcane varieties cultivated in Brazil and Australia (Boddey et al. 2000). In the case of the Immunocapture technique it was possible to detect $G$. diazotrophicus in plant tissues but not in soil collected between rows of sugarcane plants grown in the field (Santos et al., unpublished data). With the PCR technique, fragments of the same size as those from G. diazotrophicus genomic DNA were detected in soil samples collected in a sugarcane field. However, G. diazotrophicus could not be reisolated from micropropagated sugarcane plants used as a trapping host (Arcanjo et al. 2000). These results suggest that the bacteria could be in a viable but non cultivable stage or that the number of the bacteria in the soil was too low to colonize the roots of the plants.

\section{Physiological and Biochemical Studies}

The physiological and biochemical studies carried out during the last 15 years on G. diazotrophicus showed that this bacterium is able to grow diazotrophically using different carbon sources in a culture medium with a $\mathrm{pH}$ much lower than that used for most of the diazotrophic bacteria (Cavalcante and Döbereiner 1988). G. diazotrophicus is able to grow at $\mathrm{pH} 3.0$ and fixes nitrogen in culture medium at pH 2.5 (Stephan et al. 1991). This bacterium does not use sucrose directly - it has an extracellular enzyme (invertase) with saccharolytic activity. This carbon source is a key compound during the isolation of the bacteria since the LGIP semi-solid medium contains $10 \%$ sucrose (crystal sugar) which is known to inhibit the growth of other diazotrophs.
The optimum $\mathrm{pH}$ for its growth is around 5.5 and one interesting characteristic is the absence of the nitrate reductase enzyme (Cavalcante and Döbereiner 1988). Nitrogenase activity is not inhibited or suppressed by high concentrations $(25 \mathrm{mM})$ of nitrate (Stephan et al. 1991), but is partially inhibited by $\mathrm{NH}_{4^{+}}$(Teixeira et al. 1987). Reis and Döbereiner (1998) demonstrated that the nitrogenase activity is less inhibited by $\mathrm{NH}_{4} \mathrm{Cl}(5 \mathrm{mM})$ when the bacteria are grown in media containing $10 \%$ sucrose as compared to $1 \%$. Studies involving a mixed culture of G. diazotrophicus and amylolytic yeast showed that $G$. diazotrophicus is able to support growth of the yeast with about $40 \%$ of the fixed nitrogen being used by this organism (Cojho et al. 1993). The form of nitrogen excreted by G. diazotrophicus during the biological nitrogen fixation process is currently unknown (Baldani et al. 1997a).

\section{Plant Dependence}

The dependence of the G. diazotrophicus on plants, the majority of which propagate vegetatively (setts-sugarcane and Pennisetum, stem cutting-sweet potato), emphasizes its endophytic life style and suggests that this is the major way of dissemination of this organism. Paula et al. (1991) demonstrated that micropropagated sugarcane and sweet potato showed high colonization of the aerial part by G. diazotrophicus when co-inoculated with mycorrizal fungi. Thermal treatment of sugarcane setts $\left(30\right.$ minutes at $52^{\circ} \mathrm{C}$ ), applied to eliminate phytopathogenic bacteria responsible for the ratoon stanting disease, did not eliminate the endophyte (Reis et al. 1994), confirming that the setts are one way of dissemination of the bacteria. In addition, it has been observed that the bacteria have a very low rate of survival in soil (Baldani et al. 1997a), although it has been demonstrated that the rate of cell death depends on the humidity at the time of inoculation into the soil (Oliveira et al. 2004). It is already known that the bacterial population is also influenced by the nutritional stage of the sugarcane plants (Reis-Jr et al. 2000) and that nitrogen fertilization also decreases the population of G. diazotrophicus 
associated with the sugarcane (Fuentes-Ramírez et al. 1999).

\section{Genetics Studies}

In the 90's, many genes involved in nitrogen fixation by $G$. diazotrophicus were cloned and sequenced (Sevilla et al. 1997, Teixeira et al. 1999). The organization of the nif, fix and mop genes is known, however the mechanisms involved in their regulation still needs further study (Lee et al. 2000). Because of its endophytic life style, this bacterium has been used as a vector to express heterologous genes of interest. One example is the expression of cry3A and crylAb genes isolated from Bacillus thuringiensis that are responsible for the entomopathogenic activity against coleopteran and lepdopeteran insects that cause damage to sugarcane plants (Salles et al. 2000, Baldani et al. 2002b).

\section{INOCULATION RESPONSE}

One way to introduce G. diazotrophicus into sugarcane plants is during the micropropagation process since the setts are naturally colonized by this bacterium. The micropropagation process eliminates both the phytopatogenic and the nitrogen-fixing bacteria. Therefore, a method to introduce selected endophytic diazotrophic strains during the acclimatization process was developed (Reis et al. 1999). The bacteria are able to infect and colonize the root tissues and aerial parts by penetrating root tip and lateral roots formed during the rooting process (James et al. 1994). At the colm base, where the tissues are heavily colonized, the bacteria move to the aerial part using the xylematic vessels (James et al. 1994, 2001). Relatively large populations of the bacteria are found in these tissues, suggesting that this is one of the main sites for nitrogen fixation due to the low oxygen level and the energy available in form of sucrose for nitrogen fixation (James et al. 1994).

Few inoculation studies have been done to evaluate the potential of $G$. diazotrophicus strains to fix nitrogen in association with sugarcane with contributions to the plant's nitrogen metabolism, because sugarcane plants are mostly propagated by setts. Nevertheless, inoculation of micropropagated sugarcane plants with the G. diazotrophicus strain PAL5 increased the aerial fresh weight of the plant by $28 \%$ (Baldani et al. 1999). Similar results were obtained when the inoculation of the strain PAL5 was done in the presence of low amounts of nitrogen fertilizer (Moraes and Tauk-Tornisielo 1997). Proof that $G$. diazotrophicus fixes nitrogen was demonstrated by inoculation of micropropagated sugarcane plants with wild-type strain PAL5 and its nif minus mutant followed by measurement of ${ }^{15} \mathrm{~N}_{2}$ gas incorporated into the plant tissues (Sevilla et al. 2001). Recent results have shown that sugarcane derives benefit from inoculation with a mixture of diazotrophic bacteria (Oliveira et al. 2002). This result was also obtained when the inoculation process is associated with mycorrizae (Muthukumarasamy et al. 1999). Other effects of $G$. diazotrophicus inoculation are related to phyto-hormone production (indol-acetic acid) which acts on initial root development which in turn benefits the whole plant as demonstrated by Fuentes-Ramírez et al. (1993). Other studies of co-inoculation involving $G$. diazotrophicus and mycorrizal fungi showed an increment in the root system of sweet potato plants as well as the uptake of some nutrients (Paula et al. 1992). The BNF contribution to sugarcane plants grown in the field for 18 months after inoculation at the micropropagated stage with a mixture of endophytic diazotrophic bacteria, was in the range of 20 to $30 \%$ of the total $\mathrm{N}$ accumulated in the plant tissues (Oliveira et al. 2003). Other measurement studies using the delta 15 technique showed that the average BNF contribution to the sugarcane varieties harvested in sugarcane producing areas in Brazil is around 30\% (Boddey et al. 2001). However, these values varied from 0 to $70 \%$ depending on the level of the molybdenum available in the soil (Polidoro 2001).

\section{Anatomical and Physiological Root RESPONSE TO INOCULATION}

The group coordinated by Dr. Olivares has carried out studies on the inoculation effect of this 
bacterium on physiological changes of the plant metabolism. The authors have demonstrated that the inoculation of different micropropagated sugarcane genotypes (mainly RB cultivars) with selected strains of G. diazotrophicus render a sort of anatomical and physiological changes over the plant host. These effects included an increase of lateral root mitotic sites as well as emerged lateral roots with changes at the root geometry by increasing the fine root portion and the overall root system (Olivares et al. 2002). Futhermore, these anatomical changes have been accomplished by an increase on the $\mathrm{H}^{+}$ATPase activity of the root cell microsomal fraction and protein contents. Besides that, studies were carried out to link the endophytic inoculation and photosyntetic processes. The results showed that the net phosynthesis, stomacal conductance, transpiration rates as well as the relative quantum dependence of photosystem II are not affected by the endophytic establishment of Herbaspirillum/G. diazotrophicus, indicating no photoinhibitor effect and no altered leaf gas exchange. The physiological changes that takes place in sugarcane during the endophytic interaction could be, in part, related to the plant growth promoting effects such as it has been observed in many experiments that includes increase of nutrient accumulation and biomass.

\section{Molecular Mechanism of the Plant-Bacteria INTERACTION}

An important feature of the plant interaction with these endophytes is that bacteria colonize most plant organs, promoting plant growth without causing any disease symptoms. It raises the question if there is an active role of the plant in the process, or if it is just a niche for bacterial growth. Since 1994, Dr. Hemerly's group from the UFRJ is addressing this question by investigating sugarcane gene expression during the association with Gluconacetobacter diazotrophicus using different approaches: (i) cDNA-AFLP fingerprinting, (ii) transcriptional profiles generated from the SUCEST (Sugarcane EST Sequencing Project) database and (iii) microarray. The novelty of this studies was to show for the first time that sugarcane might be actively involved in the association, because several genes involved in different plant physiological processes were identified as candidates to be differentially expressed during the association (Nogueira et al. 2001). The group focus now the studies on the characterization of signaling pathways by which sugarcane plants can decipher bacterial signals and respond properly for a successful association (Vargas et al. 2003); and the molecular mechanisms that promote plant growth by association with the endophytes. By using functional genomic tools, a group of genes related to nitrogen metabolism and plant development are being characterized, in order to understand how plants benefit by this association. In addition, receptors involved in signaling plant/bacteria interactions are also being studied. The data observed for most of the studied genes indicate that the modulated gene expression during association is not a general stress response against microorganisms, but seems to be specific for benefic associations. Interestingly, the data showed that expression of several genes is not altered in sugarcane genotypes with low contributions of BNF, indicating that the plant genotype has an important role on the efficiency of the association.

\section{Genomic and Proteomic Studies}

The economical potential for the use of G. diazotrophicus for the inoculation of sugarcane cultivated in the Rio de Janeiro State and Brazil stimulated the creation of a network to sequence the genome of this bacterium. The collaborative network called RIOGENE is supported by FAPERJ and CNPq and has the participation of Embrapa Agrobiologia, four universities (UFRJ, UFRRJ, UENF and UERJ) and Laboratório Nacional de Computação Científica (LNCC). The aim of the project is to obtain the genome sequence by the end of this year with a goal to understand gene functions and consequently their manipulation to increase the efficiency of the plant/bacteria interaction and nitrogen fixation. A proteomic network was created to support the sequencing program of $G$. diazotrophicus. 


\section{Burkholderia spp}

The last group of diazotrophic bacteria showing endophytic characteristics, but not as well studied as those described above, was renamed in the last decade (Yabuuchi et al. 1992). This new genus called Burkholderia consists of 47 species, however only three are known to fix nitrogen (Gillis et al. 1995, Zhang et al. 2000, Reis et al. 2004). The first, named B. vietnamiensis, was isolated from the rhizosphere of rice roots cultivated in the Vietnam (Gillis et al. 1995). This nitrogen-fixing species also included two strains isolated from human materials belonging to the older Pseudomonas cepacea species, demonstrating that the new genus is not restricted to plant materials. The other species called B. kururiensis was isolated in Japan from an aquifer area contaminated with trichloroethylene (TCE) (Zhang et al. 2000). The ability of this species, represented only by one isolate, to fix nitrogen was demonstrated by Santos et al. (2001) in a study that compared different Burkholderia strains isolated from plants grown in Mexico and from other countries including Brazil.

In the mid 90's, a large number of nitrogenfixing bacteria, with characteristics similar to those of the Burkholderia genus, were isolated from rice, sugarcane and sweet potato plants using semi-solid JMV medium containing mannitol as a carbon source with the $\mathrm{pH}$ adjusted to near 4.5 (Baldani 1996). The partial sequence of the $23 \mathrm{~S}$ and $16 \mathrm{~S}$ rDNA region of two representative strains (M130 and Ppe8) indicated that these isolates belong to the genus Burkholderia, but they were not B. vietnamiensis species. Later, studies using probes derived from the sequenced regions from M130 and Ppe8 showed the presence of two distinct groups, one formed by the rice, manhiot and sweet potato isolates and the other by the isolates from sugarcane (Hartmann et al. 1995).

Burkholderia tropica - Based on the morphological, physiological and genetic characteristics, two new species were proposed: $B$. brasilensis (Baldani et al. 1997b) and B. tropicalis (Kirchhof et al. 1997, Reis et al. 2000). Recent studies showed that the B. brasilensis strain M130 and the B. kururiensis strain KP23 showed the same ARDRA pattern (Santos et al. 2001) with a similarity of $99.9 \%$ between the 16S rDNA subunits, suggesting that these two strains belong to the same species. Partial sequencing of the nifH and $\operatorname{gn} B$ genes also showed that these strains (M130 and KP23) were similar but distinct from the reference PPe8 strain belonging to the $B$. tropicalis species (Marin et al. 2003). DNA: DNA experiments are been carried out to define either the $B$. brasilensis isolates constitute a new species or belongs to the $B$. kururiensis species. On the other hand, the proposed name of $B$. tropicalis was offically accepted as B. tropica (Reis et al. 2004).

\section{Morphological and Physiological Studies}

Among the morphological and physiological characteristics that distinguish the two species are: $\mathrm{pH}$ tolerance, use of carbon sources, colony type grown in JMV medium containing nalidixic acid, and osmotic tolerance. The "B. brasilensis" species grows and fixes nitrogen in semi-solid JMV medium with a $\mathrm{pH}$ range of 4.0 to 6.0 with mannitol or $+\mathrm{D}, \mathrm{L}-$ carnitine as carbon sources. This strain, however, does not grow in semi-solid LGIP medium with $10 \%$ sucrose. The colonies in semi-solid JMV medium are brownish and become irregular, smooth and transparent in the presence of nalidixic acid. " $B$. brasilensis" strains are able to oxidize the following carbon sources (Biolog test): maltose and xylitol but not D-lactose and L-raffinose. On the other hand, the B. tropica species grows and fixes nitrogen in semi-solid JMV medium with a $\mathrm{pH}$ higher than 5.0 with one of the following carbon sources: mannitol, +arginine, +adipate or +ribose. It is able to fix nitrogen in semi-solid JMV medium with $10 \%$ of sucrose. Colonies grown on Potato medium with $10 \%$ crystal sugar are light brown and when grown in LGIP medium the colonies are orange with brownish borders. Colonies in JMV medium (pH 5.5) containing $2.5 \mu \mathrm{g} / \mathrm{L}$ of nalidixic acid are rounded, and orange with yellow borders. 
B. tropica strains are able to oxidize the following carbon sources (Biolog test): D-lactose and Lraffinose, but not maltose and xylitol. Strains from both species can be identified through the hybridization with probes based on the sequences of the $16 \mathrm{~S}$ ribosomal subunits. The " $B$. brasilensis" species can be identified using the Bbra62 and Bbra636 probes while the $B$. tropica species can be identified using the Btrop636 and Btrop463 probes (Boddey 2003).

\section{ECOLOGICAL STUdies}

Studies on the ecological distribution of these species demonstrated their high frequency of occurrence (especially "B. brasilensis") in sugarcane plants grown in different regions of Brazil and in Australia (Boddey 2003). "B. brasilensis" has also been isolated from different rice varieties grown in soil from Rio de Janeiro State and the Cerrado soil from Goiás (Rodrigues et al. 2001). Strains from these two species were also isolated from banana and pineapple (Weber et al. 1999) and their identity was confirmed by the partial sequencing of the $16 \mathrm{~S}$ rDNA subunit (Cruz et al. 2001). The infection and colonization process of rice by "Burkholderia brasilensis" strain M209 showed that the bacteria first colonize the root surface and than penetrate the cells via the intercellular spaces of the damaged membrane (Baldani et al. 1997a). The bacteria can also penetrate through wounds in the epidermal cell region and points of emergence in the secondary roots (Baldani et al. 1995). Additional studies showed that these species also colonize the stomata of rice seedlings (Silva et al. 2000). The infection and colonization process of micropropageted sugarcane roots inoculated with the strain Ppe8 of Burkholderia tropica was very similar to that observed for other endophytic bacteria (Boddey et al. 1999). Large populations of strain Ppe8 are mainly found on the surface of micropropagated sugarcane roots, when this strain is inoculated together other endophytic diazotrophic bacteria (Oliveira et al. 2002).

\section{INOCULATION RESPONSES}

Several inoculation experiments have been carried out to determine the BNF contribution to graminaceous plants by these Burkholderia species. Rice varieties grown in low fertility acid soil in Vietnam inoculated with the Burkholderia vietnamiensis TVV75 strain gave yield increases of 13 to $22 \%$ (Tran Van et al. 2000). In Brazil, a detailed study has been conducted involving strains of "Burhkolderia brasilensis" and different rice varieties with the goal to select those strains that are more efficient in the association leading to a greater contribution to the development of the plant (Baldani 1996). The results show that an interaction exists between the strain and rice cultivar (Baldani et al. 2000). A BNF contribution on the order of 20 and $30 \%$, as determined by the ${ }^{15} \mathrm{~N}$ isotopic dilution technique was observed in rice plants grown under gnotobiotic and greenhouse conditions (Baldani et al. 2000). The yield response of the same rice cultivars grown in the field and inoculated with these strains was very variable (Guimarães et al. 2000). A yield increase of $54 \%$ was observed for the IAC4440 rice variety inoculated with "Burkholderia brasilensis" strain M209, however the increase was very low for the IR42 variety inoculated with this strain (Guimarães et al. 2002). The results suggest that BNF research on rice should be increased considering the progress that has been made. One aspect that should be exploited should be the plant/bacteria interaction as well as interactions between bacteria as has been observed for sugarcane inoculated with a mixture of bacteria (Oliveira et al. 2002).

\section{PERSPECTIVES}

A historical analysis of studies on BNF in Graminaceous plants demonstrates significant advances in several aspects of plant/bacteria interactions. However, the expectation that the nitrogen fixation efficiency might be equivalent to the rhizobia /legume symbiosis did not turn out to be true, although the endophytic diazotrophic bacteria/plant association 
shows some characteristics that are similar to the legume symbiosis. A biotechnological program devoted to defining the functionality of genes present in most of the nitrogen-fixing bacteria as well as knowledge generated by genome sequences of several plants of agronomic interest, should contribute to a better understanding of these associations, particularly the endophytic ones. Consequently, it may be feasible to convert the potential of this association into a standard inoculation practice in agriculture. However, responses similar to those observed for the Brazilian soybean should not be expected for cereals and other grasses inoculated with endophytic diazotrophic bacteria. As has been emphasized in most of Dr Johanna Döbereiner's papers, breeding programs with Graminaceous plants should always take the interaction of endophytic diazotrophic bacteria and plant genotype into account so that the biological nitrogen fixation process can be optimized.

\section{ACKNOWLEDGMENTS}

The authors thank Dr. Fábio Pedrosa, Dr. Irene Schrank, Dr. Lucy Seldin, Dr. Fátima Moreira, Dr. Adriana Hemerly and Dr. Fábio Lopes Olivares for providing information that helped to enrich this review dedicated to the memory of Jöhanna Döbereiner. Thanks also go to Dr. Paul Bishop for reviewing the manuscript and to the Conselho Nacional de Desenvolvimento Científico e Tecnológico/Programa de Apoio a Núcleos de Excelência (CNPq/ Pronex II) for financial support of the research carried out by the group of Excellence on Biological Nitrogen Fixation in Non-leguminous Plants.

\section{RESUMO}

A presente revisão aborda a história da Fixação Biológica de Nitrogênio (FBN) em Gramíneas no Brasil, procurando mostrar a evolução da pesquisa na área iniciada a mais de 40 anos sob a liderança da pesquisadora Johanna Döbereiner. Um aspecto marcante deste período foi a descoberta de diversas bactérias fixadoras de nitrogênio atmosférico tais com as rizosféricas (Beijerinckia fluminensis e Azotobacter paspali), associativas (Azospirillum lipoferum, A. brasilense, A. amazonense) e as endofíticas
(Herbaspirillum seropedicae, H. rubrisubalbicans, Gluconacetobacter diazotrophicus, Burkholderia brasilensis e B. tropica). O papel destas bactérias diazotróficas em associação com as gramíneas, especialmente os cereais, tem sido estudado e muito se avançou sobre os aspectos ecológicos, fisiológicos, bioquímicos e genéticos. Os mecanismos de colonização e infecção dos tecidos das plantas foram melhor entendidos e a contribuição da FBN para o sistema solo-planta foi determinado. Estudos de inoculação de cereais com bactérias diazotróficas, têm mostrado que as endofíticas têm um maior potencial de contribuição da FBN e que o genótipo da planta influencia na associação da planta/bactéria. Os avanços alcançados apontam para uma maior exploração e entendimento desta associação endofítica. Os programas de sequenciamento do genoma: RIOGENE (Gluconacetobacter diazotrophicus) e GENOPAR (Herbaspirillum seropedicae) mostram a importância da FBN no Brasil e devem permitir que o país continue na fronteira do conhecimento em relação ao processo de FBN em gramíneas.

Palavras-chave: bactéria endofítica, diazotrófica, meio semi-sólido, inoculação, cereais, planta forrageira.

\section{REFERENCES}

Abrantes GTV, Day JM, CruZ VF and Döbereiner J. 1976a. Métodos para o estudo da atividade da nitrogenase em raízes de gramíneas colhidas no campo. In: Congresso Brasileiro de Ciência do Solo, 15, Sociedade Brasileira de Ciência do Solo, Campinas, SP, Brasil, p. 137-142.

Abrantes GTV, Day JM, Cruz VF and Döbereiner J. 1976b. Fatores limitantes da fixação de nitrogênio em campo de Digitaria decumbens v. transvala. In: Congresso Brasileiro de CiênCIa do Solo, 15, Sociedade Brasileira de Ciência do Solo, Campinas, SP, Brasil, p. 171-176.

Araújo EF, Zaha A, Schrank IS and Santos DS. 1988. Characterization of DNA segments adjacents to the nifHDK genes of Azospirillum brasilense $\mathrm{Sp} 7$ by Tn5 site-directed mutagenesis. In: KLINGMÜLLER W (Ed), Azospirillum IV: Genetics, Physiology and Ecology. Berlin: Springer Verlag, p. 16-25.

Arcanjo SS, Santos ST, Teixeira KRS and Baldani JI. 2000. Occurrence and dissemination of endophytic diazotrophic bacteria in sugarcane fields. In: Pedrosa FO, Hungria M, Yates G and Newton 
WE (Eds), Nitrogen fixation: from molecules to crop productivity. (Current Plant Sciences and Biotechnology in Agriculture 38) Dordrecht: Kluwer, 605 p.

Ashbolt NJ And Inkerman PA. 1990. Acetic acid bacterial biota of the pink sugar cane mealybug Saccharococus sacchari and its environs. Appl Environ Microbiol 56: 707-712.

Assmus B, Hutzler P, Kirchiof G, Amann R, LawREANCE JR AND HARTMANN A. 1995. In situ localization of Azospirillum brasilense in the rhizosphere of wheat with fluorescently labelled, rRnatargeted oligonucleotide probes and scanning confocal laser microscopy. Appl Environ Microbiol 61: 1013-1019.

BALDANi JI. 1984. Ocorrência e caracterização de Azospirillum amazonense em comparação com outras espécies deste gênero em raízes de milho, sorgo e arroz, M.Sc. Thesis, Universidade Federal Rural do Rio de Janeiro, RJ, Brasil.

Baldani Ji, Pereira PAA, Neyra CA and DöbereINER J. 1978. The initiation of acetylene reduction in isolated roots of maize: effect of carbon, oxygen and mineral nitrogen sources. In: DöBEREINER J, Burris RH ANd Hollaender A (Eds), Limitations and potentials for biological nitrogen fixation in the tropics. Basic Life Sciences, 10, New York: Plenum, p. 356-357.

Baldani Ji, Blaña RAG and Döbereiner J. 1979. Efeito do genótipo do milho na atividade da nitrogenase e da nitrato redutase. Pesq Agropec Bras 14: $165-173$.

Baldani JI, Pereira PAA, Rocha REM ANd DöBeREINER J. 1981. Especificidade na infecção de raízes por Azospirillum spp em plantas com via fotossintética $\mathrm{C}_{3}$ e $\mathrm{C}_{4}$. Pesq Agropec Bras 16: 325-330.

Baldani JI, Baldani VLD, Xavier DF, Boddey RM AND DöBereiner J. 1982. Efeito da calagem no número de actinomicetos e na porcentagem de bactérias resistentes à estreptomicina na rizosfera de milho, trigo e feijão. Rev Microbiol 13: 250-263.

BALDANi JI, BALDANi VLD, SAMPaio MJAM ANd DöBEREINER J. 1984. A fourth Azospirillum species from cereal roots. An Acad Bras Cienc 56: 365.

Baldani JI, Baldani VLD, SEldin L ANd DöBereINER J. 1986a. Characterization of Herbaspirillum seropedicae gen. nov., sp. nov., a root-associated nitrogen-fixing bacterium. Int J Syst Bacteriol 36: 86-93.

BALDANI JI ET AL. 1996. Emended description of Herbaspirillum; a mild plant pathogen, as Herbaspirillum rubrisubalbicans comb. nov.; and classification of a group of clinical isolates (EF group 1) as Herbaspirillum species 3. Int J Syst Bacteriol 46: 802-810.

Baldani Ji, Caruso LV, Baldani VLD, Goi SR and DöBEREINER J. 1997a. Recent advances in BNF with non-legume plants. Soil Biol Biochem 29: 911-922.

Baldani JI, Azevedo MS, Reis VM, Teixeira KRS, Olivares FL, Goi SR, Baldani VLD and DöbeREINER J. 1999. Fixação biológica de nitrogênio em gramíneas: avanços e aplicações. In: SiQUEIRA JO, Moreira FMS, Lopes AS, GHILHERme LRG, Faquin V, Furtini Neto AE and Carvalho JG (Eds), Inter-relação fertilidade, biologia do solo e nutrição de plantas. Viçosa: SBCS/UFLA, p. 621-666.

BALDANi JI, REIS VM, BALDANi VLD AND DöBEREINER J. 2002a. A brief story of nitrogen fixation in sugarcane - reasons for success in Brazil. Funct Plant Biol 29: 417-423.

Baldani JI, Salles JF and Olivares FL. 2002b. Bactérias endofíticas como vetores de genes de resistencia a insetos. In: Melo IS, Valadares-Inglis MC, Nass LL and Valois ACC (Eds), Recursos genéticos e melhoramento - microrganismos. Jaguariúna: Embrapa Meio Ambiente, p. 589-601.

BALdani VLD. 1996. Efeito da inoculação de Herbaspirillum spp. no processo de colonização e infecção de plantas de arroz e ocorrência e caracterização parcial de uma nova bactéria diazotrófica. DSc Thesis, Universidade Federal Rural do Rio de Janeiro, RJ, Brasil.

BALDANi VLD AND Döbereiner J. 1980. Host-plant specificity in the interaction of cereals with Azospirillum spp. Soil Biol Biochem 12: 433-439.

BAldani VLD, Baldani JI ANd DöBereiner J. 1983. Effects of Azospirillum inoculation on the root infection and nitrogen incorporation in wheat. Can $\mathbf{J}$ Microbiol 29: 433-439.

Baldani VLD, Alvarez MA, Baldani JI ANd DöbereINER J. 1986b. Establishment of inoculated Azospirillum spp. in the rhizosphere and in roots of field grown wheat and sorghum. Pl Soil 90: 35-46. 
Baldani VLD, Baldani JI, Olivares FL and DÖBereINER J. 1992a. Identification and ecology of Herbaspirillum seopedicae and the closely related Pseudomonas rubrisubalbicans. Symbiosis 19: 65-73.

Baldani VLD, James EK, Baldani JI and DöbereINER J. 1992b. Colonization of rice by the nitrogenfixing bacteria Herbaspirillum spp. and Azospirillum brasilense. In: International Congress on Nitrogen Fixation, 9, Cancun, México, 860 p.

BaLdaNi VLD, Goi SR, BaLdani JI and Döbereiner J. 1995. Localization of Herbaspirillum spp and Burkholderia sp. in rice root system. In: INTERNational Symposium on Microbiol Ecology, 7 , Santos, SP, Brasil, 133 p.

Baldani VlD, Oliveira E, Balota E, Baldani Ji, KIRCHHOF G AND DöBEREINER J. 1997b. Burkholderia brasilensis sp. nov., uma espécie de bactéria diazotrófica endofítica. An Acad Bras Cienc 69: 116.

BALDANi VLD, BaLdani JI AND DöBereiner J. 2000. Inoculation of rice plants with endophytic diazotrophs Herbaspirillum seropedicae and Burkholderia spp. Biol Fertil Soil 30: 485-491.

Bashan Y and Holguin G. 1997. Azospirillum-plant relationships: environmental and physiological advances (1990-1996). Can J Microbiol 43: 103-121.

Benelli EM, Souza EM, Funayama S, Rigo LU and Pedrosa FO. 1997. Evidence for two possible $g \ln B$ type genes in Herbaspirillum seropedicae. J Bacteriol 179: 4623-4626.

Benelli EM, Buck M, Souza EM and Pedrosa FO. 2001. Uridylylation of the PII protein from Herbaspirllum seropedicae. Can J Microbiol 47: 309-314.

Benelli EM, Buck M, Polikarpov L, Souza EM, Cruz LM and Pedrosa FO. 2002. Herbaspirillum seropedicae signal transduction protein PII is structurrally similar to the enteric GlnK. Eur J Biochem 269: 3296-3303.

BoDDEy LH. 2003. Ocorrência e diversidade de bactérias diazotróficas do gênero Burkholderia, isoladas de cana-de-açúcar (Saccharum sp.) cultivadas na Austrália e no Brasil. DSc Thesis, Universidade Federal Rural do Rio de Janeiro, RJ, Brasil.

Boddey LH, BALDANI JI AND GoI SR. 1999. Localização de Burkholderia spp. em plantulas micropropagadas de cana-de-açúcar. In: CoNGREsSo Brasileiro de Microbiologia, 20, Salvador, BA, Brasil, Resumo MB-72.
BODDEY RM AND DÖBEREINER J. 1982. Association of Azospirillum and other diazotrophs with tropical gramineae. In: International Congress of SoIL ScIence, 12, New Delhi, India. Non-symbiotic nitrogen fixation and organic matter in the tropics, p. 28-47.

Boddey RM, Chalk PM, Victoria RL, Matsui E and DöBEREINER J. 1983. The use of the ${ }^{15} \mathrm{~N}$-isotope dillution technique to estimate the contribution of associated biological nitrogen fixation to the nitrogen nutrition of Paspalum notatum cv. batatais. Can J Microbiol 39: 1036-1045.

Boddey RM, BaLdani VLD, Baldani JI AND DöBeREINER J. 1986. Effect of inoculation of Azospirillum spp. on nitrogen accumulation by field-grown wheat. Pl Soil 95: 109-121.

Boddey RM, Silva G, Reis VM, Alves BJR and URQUiaga S. 2000. Assessment of bacterial nitrogen fixation in grass species. In: TRIPLET E (Ed), Prokariotic nitrogen fixation: a model system for analysis of a biological process. Wymondham, UK: Horizon Scientific, p. 705-726.

Boddey RM, Polidoro JC, Resende AS, Alves BJR AND Urquiaga S. 2001. Use of the ${ }^{15} \mathrm{~N}$ natural abundance technique for the quantification of the contribution of $\mathrm{N}_{2}$ fixation sugar cane and other grasses. Aust J Plant Physiol 28: 889-895.

Bothe H, Klein B, Stephan MP and Döbereiner J. 1981. Transformations of inorganic nitrogen by Azospirillum spp. Arch Microbiol 130: 96-100.

Caballero-Mellado J and Martinez-Romero E. 1994. Limited genetic diversity in the endophytic sugarcane bacterium Acetobacter diazotrophicus. Appl Environ Microbiol 60: 1532-1537.

CAMpÊlo AB ANd DöBereiner J. 1970. Ocorrência de Derxia sp. em solos de alguns estados brasileiros. Pesq Agropec Bras 5: 327-332.

Cavalcante VA and Döbereiner J. 1988. A new acidtolerant nitrogen-fixing bacterium associated with sugarcane. Pl Soil 108: 23-31.

Cojho EH, ReIs VM, Schenderg AC ANd DöBEREINER J. 1993. Interactions of Acetobacter diazotrophicus with an amylolytic yeast in nitrogen-free batch culture. FEMS Microbiol Lett 106: 341-346.

Cruz LM, Souza EM, Weber OB, Baldani JI, DöbeREINer J AND Pedrosa FO. 2001. rDNA character- 
ization of new nitrogen-fixing bacteria from Banana (Musa spp) and pineapple (Ananas comusus (L) Merril). Appl Environ Microbiol 67: 2375-2379.

DAy JM And Döbereiner J. 1976. Physiological aspects of $\mathrm{N}_{2}$ fixation by a Spirillum from Digitaria roots. Soil Biol Biochem 8: 45-50.

Day JM, Neves MCP ANd Döbereiner J. 1975. Nitrogenase activity on the roots of tropical forage grasses. Soil Biol Biochem 7: 107-112.

Dekhil SB, Cahill M, Stackbrandt E and Sly LI. 1997. Transfer of Conglomeromonas largomobilis subs. largomobilis to the genus Azospirillum as Azospirillum lagomobile comb. nov., and elevation of Conglomeromonas largomobilis subs. parooensis to the new type species of Conglomeromonas, Conglomeromonas parooensis sp. nov. Syst Appl Microbiol 20: 72-77.

De-Polli H and Döbereiner J. 1980. Diazotrophic rhizocoenoses. In: STEWART WDP AND Gallon JR (Eds), Nitrogen fixation. London: Academic, p. 301-333.

De-Polli H, Matsui E, Döbereiner J and Salati E. 1977. Confirmation of nitrogen fixation in two tropical grassses by ${ }^{15} \mathrm{~N}_{2}$ incorporation. Soil Biol Biochem 9: 119-123.

De-Polli H, Bohlool BB and Döbereiner J. 1980. Serological differentiation of Azospirillum species belonging to different host-plant specificity groups. Arch Microbiol 126: 217-222.

DöBereiner J. 1953. Azotobacter em solos ácidos. Bol Inst Ecol Exp Agr 11: 1-36.

DöBEREINER J. 1959a. Sobre a ocorrência de Beijerinckia em alguns solos do Brasil. Rev Bras Biol 19: 151160 .

DöBEREINER J. 1959b. Influência da cana-de-açúcar na população de Beijerinckia do solo. Rev Bras Biol 19: 251-258.

DöBEREINER J. 1961. Nitrogen-fixing bacteria of the genus Beijerinckia Derx in the rhizosphere of sugar cane. Pl Soil 15: 211-216.

DöBereiner J. 1966. Azotobacter paspali sp. nov., uma bactéria fixadora de nitrogênio na rizosfera de Paspalum. Pesq Agropec Bras 1: 357-365.

DöBEREINER J. 1968. Non-symbiotic nitrogen fixation in tropical soils. Pesq Agropec Bras 3: 1-6.
DöBEREINER J. 1970. Fürther research on Azotobacter paspali and its variety specific occurrence in the rhizosphere of Paspalum notatum Flügge. Zentralb Bakteriol Parasint Infektion Hyg 124: 224-230.

DöBEREINER J. 1973. Fixação de nitrogênio atmosférico na rizosfera de gramíneas tropicais. In: CONFERÊNCIA InTERnacional Sobre os ImPactos Globais DA Microbiologia Aplicada, 4, São Paulo, SP, Brasil, p. $461-481$.

DöBEREINER J. 1976. Fixação de nitrogênio atmosférico em gramíneas tropicais. In: CONGRESSO BrasILEIRO DE CiênCIA do Solo, 15, Campinas, SP, Brasil, p. 593-602.

DöBEREINER J. 1977a. Biological nitrogen fixation in tropical grasses - Possibilities for partial replacement of mineral $\mathrm{N}$ fertilizers. AMBIO; J Human Environ Res Manag 6: 174-177.

DöBEREINER J. 1977b. N 2 -fixation associated with nonleguminous plants. In: Hollaender A (Ed), Genetic engineering for nitrogen fixation. New York: Plenum, p. 451-461.

DöBEREINER J. 1977c. Plant genotype effects on nitrogen fixation in grasses. In: Muhammed A, Askel R AND Borstel RC vON (Eds), Genetic diversity in plants. Basic Life Sciences, 8, New York: Plenum, p. 325-334.

DöBEREINER J. 1978. Influence of environmental factors on the occurence of Spirillum lipoferum in soil and roots. In: Granhall U (Ed), Environmental role of nitrogen-fixing blue-green algae and asymbioitc bacteria. Ecological Bulletins, 26, Stockholm: Swedish Natural, p. 343-352.

Döbereiner J. 1979. Fixação de nitrogênio em gramíneas tropicais. Interciência 4: 200-205.

DöBEREINER J. 1992a. Recent changes in concepts of plant bacteria interactions: Endophytic $\mathrm{N}_{2}$ fixing bacteria. Ci Cult 44: 310-313.

DöBEREINER J. 1992b. History and new perspectives of diazotrophs in association with non-leguminous plants. Symbiosis 13: 1-13.

Döbereiner J ANd Alvahydo R. 1959. Sobre a influência da cana-de-açúcar na ocorrência de Beijerinckia no solo: Influência das diversas partes do vegetal. Rev Bras Biol 19: 401-412.

DöBereiner J AND BALdANi VLD. 1979. Selective infection of maize roots by streptomycin-resistant 
Azospirillum lipoferum and other bacteria. Can J Microbiol 25: 1264-1269.

DöBereiner J AND CAMPÊLo AB. 1971. Non-symbiotic nitrogen fixing bacteria in tropical soils. Pl Soil, special vol, p. 457-470.

DöBereiner J AND CASTro AF. 1955. Ocorrência e capacidade de fixação de nitrogênio de bactérias do gênero Beijerinckia nas séries de solos da área territorial do Centro nacional de ensino e pesquisas agronômicas. Bol Inst Ecol Exp Agric 16: 1-18.

DöBereiner J AND DAY JM. 1975. Associative symbioses in tropical grasses: charcaterization of microganisms and nitrogen-fixing sites. In: INTERNAtional Symposium on Nitrogen Fixation, 1, Washington State University, Pullman, WA, USA, p. 518-538.

Döbereiner J and Pedrosa FO. 1987. Nitrogen-fixing bacteria in Nonleguminous crop plants. Brock/Springer Series in Contemporary/Bioscience, $155 \mathrm{p}$.

DöBEREINER J AND Ruschel AP. 1958. Uma nova espécie de Beijerinkia. Rev Biol 1: 261-272.

DöBEREINER J AND Ruschel AP. 1961. Inoculação do arroz com bactérias fixadoras de nitrogênio do gênero Beijerinckia Derx. Rev Bras Biol 21: 397-407.

DÖBEREINER J, DAY JM AND DART PJ. 1972a. Nitrogenase activity in the rhizosphere of sugaracane and some other tropical grasses. Pl Soil 37: 191-196.

DöBereiner J, DAy JM AND DART PJ. 1972b. Nitrogenase activity and oxygen sensitivity of the Paspalum notatum - Azotobacter paspali association. J Gen Microbiol 71: 103-116.

Döbereiner J, DAy JM ANd DART PJ. 1973. Fixação de nitrogênio na rizosfera de Paspalum notatum e da cana-de-açúcar. Pesq Agropec Bras Ser Agron 8: 153-157.

Döbereiner J, Marriel IE ANd Nery M. 1976. Ecological distribution of Spirillum lipoferum Beijerinck. Can J Microbiol 22: 1464-1473.

DöBEREINER J, ReIS VM AND LAZARINi AC. 1988. New $\mathrm{N}_{2}$-fixing bacteria in association with cereals and sugarcane. In: Bothe H, DE BRuiJn FJ AND NewTON WE (Eds), Nitrogen fixation: hundred years after. Stuttgart: Gustav Fischer, p. 717-722.

Döbereiner J, Pimentel JP, Olivares FL and URQUiAGA S. 1990. Bactérias diazotróficas podem ser endofíticas ou fitopatogênicas? An Acad Bras Cienc 62: 319 .
Döbereiner J, Reis VM, PAula MA ANd Olivares FL. 1993. Endophytic diazotrophs in sugar cane, cereals and tuber plants. In: Palacios R, Mora J AND Newton WE (Eds), New horizons in nitrogen fixation. Current Plant Science and Biotechnology in Agriculture 17, Dordrecht: Kluwer, p. 671-676.

Döbereiner J, Baldani VLD, Olivares FL and Reis VM. 1994. Endophytic diazotrophs: The key to BNF in gramineous plants. In: HegASI NA, FAYEZ M AND Monib M (Eds), Nitrogen fixation with nonlegumes. The American University in Cairo Press, Egypt, p. 395-408.

Dommergues Y, Balandreau JP, Rinaudo G AND WEINHARD P. 1973. Non symbiotic nitrogen fixation in the rhizosphere of rice, maize and diffrent tropical grasses. Soil Biol Biochem 5: 83-89.

Eckert B, Weber OB, Kirchhof G, Halbritter A, Stoffels M and Hartmann A. 2001. Azospirillum doebereinerae sp. nov., a new nitrogen-fixing bacterium associated with the C4-grass Miscanthus. Int J Syst Evolut Microbiol 51: 17-26.

Elbeltagy A, Nishioka K, Sato T, Suzuki H, Ye B, Hamada T, Isawa T, Mitsui H and MinamiSAWA K. 2001. Endophytic colonization and in planta nitrogen fixation by a Herbaspirillum sp. isolated from wild rice species. Appl Environ Microbiol 67: 5285-5293.

FADEL-Picheth CMT, Souza EM, Rigo LU, FunAyama S ANd Pedrosa FO. 1999. Regulation of the nifA gene of Azospirillum brasilense by ammonium and oxygen. FEMS Microbiol Lett 179: 281-288.

Ferreira MCB, Fernandes MS And Döbereiner J. 1987. Role of Azospirillum brasilense nitrate reductase in nitrate assimilation by wheat plants. Biol Fertil Soils 4: 47-53.

Frazzon J AND Schrank IS. 1998. Sequencing and complementation analysis of the nifUSV genes from Azospirillum brasilense. FEMS Microbiol Lett 159: 151-158.

Freitas JLM, Rocha REM, Pereira PAA and DöbeREINER J. 1982. Matéria orgânica e inoculação de Azospirillum na incorporação de N pelo milho. Pesq Agropec Bras 17: 1423-1432.

Fuentes-Ramírez LE, Jimenez-SAlgado T, AbarcaOcampo IR and Caballero-Mellado J. 1993. Acetobacter diazotrophicus, an indoleacetic acid pro- 
ducing bacterium isolated from sugarcane cultivars of México. Pl Soil 154: 145-150.

Fuentes-Ramírez LE, Caballero-Mellado J, Sepúlveda J AND Martínez-Romero E. 1999. Colonization of sugarcane by Acetobacter diazotrophicus is inhibited by high $\mathrm{N}$ fertilization. FEMS Microbiol Ecol 29: 117-128.

Fuentes-Ramírez LE, Bustilios-Cristales R, TAPIAHernandez A, Jimenez-SAlgado T, WANG ET, Martinez-Romero E and Caballero-Mellado J. 2001. Novel nitrogen-fixing acetic acid bacteria, Gluconacetobacter johannae sp. nov. and Gluconacetobacter azotocaptans sp. nov. associated with coffee plants. Int J Syst Evolut Microbiol 51: 1305-1314.

Gillis M, Kersters K, Hoste B, Janssens D, KropPenstedt RM, Stephan MP, Teixeira KRS AND DöBEREINER J. 1989. Acetobacter diazotrophicus sp. nov., a nitrogen-fixing acetic acid bacterium associated with sugarcane. Int J Syst Bacteriol 39: 361-364.

Gillis M, Döbereiner J, Pot B, Goor M, Falsen E, Hoste B and Kersters K. 1991. Taxonomic relationships between [Pseudomonas] rubrisubalbicans, some clinical isolates (EF group 1), Herbaspirillim seropedicae and [Aquaspirillum] autotrophicum. In: Polsinelli M, Materassi R AND Vincenzini M (Eds), Nitrogen fixation. Development in Plant and Soil Sciences 48, Dordrecht: Kluwer, p. 293-294.

Gillis M, Tran Van T, Bardin R, Goor M, Herbar P, Willems A, Segers P, Kersters K, Heulin T And Fernandez MP. 1995. Polyphasic taxonomy in the genus Burkholderia leading to an emended description of the genus and preposition of Burkholderia vietnamiensis sp. nov. for $\mathrm{N}_{2}$-fixing isolates from rice in Vietnam. Int J Syst Evol Microbiol 45: 274-289.

Guimarães SL, Silva RA, Baldani JI, Baldani VLD AND DÖBEREINER J. 2000. Effects of the inoculation of endophytic diazotrophic bacteria on grain yield of two rice varieties (guarani and CNA 8305) grown under field conditions. In: Pedrosa FO, Hungria M, Yates G and Newton WE. Nitrogen fixation: from molecules to crop productivity. Current Plant Sciences and Biotechnology in Agriculture, 38, Dordrecht: Kluwer, 431 p.
Guimarães SL, BALdANi JI AND BALDANI VLD. 2002. Influência da inoculação com bactérias diazotróficas endofíticas na produção de grãos de arroz inundado crescido sob condições de campo. In: Congresso da Cadeia Produtiva de Arroz, 1., Reunião NaCiOnAl de Pesquisa de Arroz, 7., Florianópolis, SC, Brasil, p. 561-564.

GyaneshWAR P, JAMES EK, REDDy PM AND LADHA JK. 2002. Herbaspirillum colonization increases growth and nitrogen accumulation in aluminium-tolerant rice varieties. New Phytol 154: 131-145.

Hartmann A And Zimmer W. 1994. Physiology of Azospirillum. In: ОкоN Y (Ed), Azospirillum/plant associations. Boca Raton: CRC, p. 15-39.

Hartmann A, Baldani Ji, Kirchhof G, Assmus B, Hutzler P, SPRinger N, LudWig W, Baldani VLD AND DöBEREINER J. 1995. Taxonomic and ecological studies of diazotrophic rhizosphere bacteria using phylogenetic probes. In: Fendrik I, Del Gallo M, Vanderleyden J and Zamaroczy M (Eds), Azospirillum VI and related microrganisms: genetics, physiology, ecology. NATO ASI Series. Series G, Ecological Sciences, 37, Berlin: Springer, p. $415-427$.

Ishida ML, Assumpção MC, Machado HB, Benelli EM, Souza EM and Pedrosa FO. 2002. Identification and characterization of the two-component NtrY/NtrX regulatory system in Azospirillum brasilense. Braz J Med Biol Res 35: 651-661.

James EK AND Olivares FL. 1998. Infection and colonization of sugarcane and other graminaceous plants by endophytic diazotrophs. Crit Rev Pl Sci 17: 77-119.

James EK, Reis VM, Olivares FL, Baldani JI AND DöBEREINER J. 1994. Infection of sugarcane by the nitrogen-fixing bacterium Acetobacter diazotrophicus. J Exp Bot 45: 757-766.

JAMES EK, OLIVARES FL, BALDANI JI AND DöBEREINER J. 1997. Herbaspirillum, an endophytic diazotroph colonizing vascular tissue in leaves of Sorghum bicolor L. Moench. J Exp Bot 48: 785-797.

James EK, Olivares FL, Oliveira ALM, Reis Jr FB, Silva LG AND REIS VM. 2001. Fürther observations on the interaction between sugar cane and Gluconacetobacter diazotrophicus under laboratory and greenhouse conditions. J Exp Bot 52: 747-760. 
Kass DC, Drosdoff M and Alexander M. 1971. Nitrogen fixation by Azotobacter paspali in association with Bahia grass (Paspalum notatum). Am J Soil Sci Proc 35: 286-289.

Khammas KM, Ageron E, Grimont PAD and Kaiser P. 1989. Azospirillum irakense sp. nov., a nitrogenfixing bacterium associated with rice roots and rhizosphere soil. Res Microbiol 140: 679-693.

Kirchhof G, Schloter M, Assmus B and Hartmann A. 1997. Molecular microbial ecology approaches applied to diazotrophs associated with non-legumes. Soil Biol Bioch 29: 853-862.

Kirchhof G, Eckert B, Stoffels M, Baldani Ji, Reis VM and Hartmann A. 2001. Herbaspirillum frisingene sp. nov., a new nitrogen-fixing bacterial species that occurs in C4-fiber plants. Int J Syst Evolut Microbiol 51: 157-168.

Klassen G, Pedrosa FO, Souza EM and Rigo LU. 1999. Sequencing and functional analysis of the nifENXorflorf 2 gene cluster of Herbaspirillum seropedicae. FEMS Microbiol Lett 181: 165-170.

KLASSEn G, Souza EM, Yates GM, Rigo L, InABa J AND Pedrosa FO. 2001. Control of nitrogenase reactivation by the GlnZ protein in Azospirillum brasilense. J Bacteriol 183: 6710-6713.

Knopik MA, Funayama S, Rigo LU, Souza EM and Pedrosa F O. 1991. Cloning of the nifA and nifB genes of Azospirillum brasilense strain Sp7. In: Polsinelli M, Materassi R and Vincenzini M (Eds), Nitrogen fixation. Development in Plant and Soil Sciences, 48, Dordrecht: Kluwer, p. 133-138.

LANGe A And Moreira FMS. 2002. Detecção de Azospirillum amazonense em raízes e rizosfera de Orchidacee e de outras famílias vegetais. Rev Bras Cienc Solo 26: 529-532.

Lee S, Reth A, Meletzus D, Sevilla M AND Kennedy C. 2000. Characterization of a major cluster of nif, fix and associated genes in a sugarcane endophyte, Acetobacter diazotrophicus. J Bacteriol 182: 7088-7091.

Lima E, Boddey RM and Döbereiner J. 1987. Quantification of biological nitrogen fixation associated with sugarcane using a ${ }^{15} \mathrm{~N}$ aided nitrogen balance. Soil Biol Biochem 19: 165-170.

Loganathan P, Sunita R, Parida AK and Nir S. 1999.
Isolation and characterization of two genetically distinct groups of Acetobacter diazotrophicus from a new host plant Eleusine coracana L. J Appl Microbiol 87: 167-172.

Machado HB, Funayama S, Rigo LU and Pedrosa FO. 1991. Excretion of ammonium by Azospirillum brasilense. Can J Microbiol 37: 549-553.

Machado HB, Yates MG, Funayama S, Rigo LU, StefFens MBR, Souza EM And Pedrosa FO. 1995. The $n t r B C$ genes of Azospirillum brasilense are part of a nifR3-like-ntrB-ntrC operon and are negatively regulated. Can J Microbiol 41: 674-684.

Machado IMP, Yates MG, Machado HB, Souza EM AND Pedrosa FO. 1996. Cloning and sequencing of the nitrogenase structural genes nifHDK of Herbaspirillum seropedicae. Braz J Med Biol Res 29: 1599-1602.

Machado WC and Döbereiner J. 1969. Estudos complementares sobre a fisiologia de Azotobacter paspali e sua dependência da planta (Paspalum notatum). Pesq Agropec Bras 4: 53-58.

Magalhães FMM, Patriquin DG and Döbereiner J. 1979. Infection of field grown maize with Azospirillum spp. Rev Bras Biol 39: 587-596.

Magalhães FMM, Baldani Ji, Souto SM, KuykenDALl JR AND DöBEREINER J. 1983. A new acid tolerant Azospirillum species. An Acad Bras Cienc 55: 417-430.

Magalhães LMS, Neyra CA and Döbereiner J. 1978. Nitrate and nitrite reductase negative mutants of $\mathrm{N}_{2}$-fixing Azospirillum spp. Arch Microbiol 117: 247-252.

Marin VA, TeiXeira KRS and Baldani JI. 2003. Characterization of amplified polymerase chain reaction $g \ln \mathrm{B}$ and nif $\mathrm{H}$ gene fragments of nitrogen-fixing Burkholderia species. Lett Appl Microbiol 36: 77-82.

Martin-Didonet CCG, Chubatsu LS, Souza EM, Kleina M, Rego FGM, Rigo LU, Yates MG and Pedrosa FO. 2000. The genome structure of the genus Azospirillum. J Bacteriol 182: 4113-4116.

Melloni R, Nóbrega RSA, Moreira FMS and SIQUEIRA JO. 2004. Densidade e diversidade de bactérias diazotróficas endofíticas em solos de mineração de bauxita em reabilitação. Rev Bras Cienc Solo 28: 85-93. 
Monteiro RA, Souza EM, Funayama S, Yates G, Pedrosa FO And Chubatsu LS. 1999a. Expression and functional analysis of an N-truncated NifA protein of Herbaspirillum seropedicae. FEBS Lett 447: 283-286.

Monteiro RA, Souza EM, Yates G, Pedrosa FO and Chubatsu LS. 1999b. In-trans regulation of the Ntruncated NifA protein of Herbaspirillum seropedicae by the N-terminal domain. FEMS Microbiol Lett 180: 157-161.

Moraes VA AND TAuK-Tornisielo SM. 1997. Efeito da inoculação de Acetobacter diazotrophicus em canade-açúcar (Saccharum spp) variedade SP70-1143, a partir de cultura de meristemas. In: Congresso Brasileiro de Microbiologia, 19, Rio de Janeiro, RJ, Brasil, 215 p.

Muthukumarasamy R, Revathi G and LakshminaRASIMHAN C. 1999. Diazotrophic associations in sugarcane cultivation in South India. Trop Agric 76: 171-178.

Nery M, Abrantes GTV, Santos D and Döbereiner J. 1977. Fixação de nitrogênio em trigo. Rev Bras Cienc Solo 1: 15-20.

Neves MCP, Day JM, Carneiro AM ANd Döbereiner J. 1976. Atividade da nitrogenase na rizosfera de gramíneas tropicais forrageiras. Rev Microbiol 7: 59-65.

Neyra CA And DöBereiner J. 1977. Nitrogen fixation in grasses. Adv Agron 29: 1-38.

Neyra CA, Döbereiner J, Lalande R AND KnOWles R. 1977. Denitrification by $\mathrm{N}_{2}$-fixing Spirillum lipoferum. Can J Microbiol 23: 300-305.

Nóbrega RSA, Moreira FMS, Siqueira JO and Lima AS. 2004. Caracterização fenotípica e diversidade de bactérias diazotróficas associativas isoladas de solos em reabilitação após a mineração de bauxita. Rev Bras Cienc Solo 28: 269-279.

Nogueira EM, Vinagre F, Masuda HP, Vargas C, de Pádua VlM, da Silva FR, dos Santos RV, Baldani JI, Ferreira PCG and Hemerly AS. 2001. Expression of sugar cane genes induced by inoculation with Gluconacetobacter diazotrophicus and Herbaspirillum rubrisubalbicans. Genet Mol Biol 24: 199-206.

Olivares FL, BALDANI JI AND DÖBEREINER J. 1995. Infection and colonization of sugaracane by the nitro- gen fixing bacteria Herbaspirillum spp. In: INTERAMERICAN CONFERENCE ON ELECTRON MicrosCOPy, 3, MeEting of the Brazilian Society FOR Electron Microscopy, 15, Caxambu, MG, Brazil, $282 \mathrm{p}$.

Olivares Fl, Baldani VLD, Reis VM, Baldani JI AND DÖBEREINER J. 1996. Occurrence of endophytic diazotroph Herbaspirillum spp in roots, stems and leaves predominantly of gramineae. Biol Fertil Soils 21: 197-200.

Olivares FL, James EK, Baldani JI ANd DöBereiner J. 1997. Infection of mottled stripe disease-susceptible and resistant sugar cane varieties by the endophytic diazotroph Herbaspirillum. New Phytol 135: 723-737.

Olivares FL, Reis VM and Façanha AR. 2002. The role of endophytic diazotrops in sugarcane root morphogenesis and development. In: FINAN TM, O'Brian MR, Layzell DB, Vessey JK and NewTON W (Eds), Nitrogen fixation: Global perspectives. Oxon: CAB International, p. 476-477.

Oliveira AlM, Urquiaga S, Döbereiner J and BalDANI JI. 2002. The effect of inoculating endophytic $\mathrm{N}_{2}$-fixing bacteria on micropropageted sugarcane plants. Pl Soil 242: 205-215.

Oliveira AlM, Canuto EL, Reis VM and Baldani JI. 2003. Response of micropropagated sugarcane varieties to inoculation with endophytic diazotrophic bacteria. Braz J Microbiol 34: 59-61.

Oliveira ALM, Canuto EL, Silva EE, Reis VM and BALDANI JI. 2004. Survival of endophytic diazotrophic bacteria in soil under different moisture levels. Braz J Microbiol 35: 295-299.

Passaglia LMP, Nunes CP, Zaha A and Schrank IS. 1991. The nifHDK operon in the free-living nitrogenfixing bacteria Azospirillum brasilense sequentially comprises genes H,D,K an 353bp ORF and gene Y. Braz J Med Biol Res 24: 649-675.

PAssaglia LMP, Schrank A AND Schrank IS. 1995. The two overlapping Azospirillum brasilense upstream activator sequences have differential effects on nifH promoter activity. Can J Microbiol 41: 849854.

Passaglia LMP, VAN Soom C, Schrank A AND SCHRANK IS. 1998. Purification and binding. Braz J Med Biol Res 31: 1363-1374. 
PATRIQUin DG AND Döbereiner J. 1978. Light microscopy observations of tetrazoluim-reducing bacteria in the endorhizosphere of maize and other grasses in Brazil. Can J Microbiol 24: 734-742.

PATRIQuin DG, Döbereiner J AND JAIn DK. 1983. Sites and processes of association between diazotrophs and grasses. Can J Microbiol 29: 900-915.

Paula MA, Reis VM, Urquiaga S and Döbereiner J. 1990. Esporos de fungo MVA Glomus clarum como veículo de infecção de Acetobacter diazotrophicus. An Acad Bras Cienc 62: 318-319.

Paula MA, Reis VM AND DöBEREINER J. 1991. Interactions of Glomus clarum with Acetobacter diazotrophicus in infection of sweet potato (Ipomoea batatas), sugarcane (Saccharum spp.), and sweet sorghum (Sorghum vulgare). Biol Fertil Soils 11: 111-115.

Paula MA, Urquiaga S, Siqueira JO and Döbereiner J. 1992. Synergistic effects of vesicular-arbuscular mycorrhizal fungi and diazotrophic bacteria on nutrition and growth of sweet potato (Ipomoea batatas). Biol Fertil Soils 14: 61-66.

Pedrosa FO and Yates MG. 1984. Regulation of nitrogen fixation (nif) genes of Azospirillum brasilense by nifA and $n t r C(\mathrm{gln})$ type genes. FEMS Microbiol Lett 23: 95-101.

Pedrosa FO ET AL. 1997. Structural organization and regulation of the nif genes of Herbaspirillum seropedicae. Soil Biol Biochem 29: 843-846.

Pedrosa Fo, Benelli EM, Yates MG, Wassem R, MonTEIRo RA, KLASSEN G, STEFFEns MBR, Souza EM, Chubatsu LS and Rigo LU. 2001. Recent developments in the structural organisation and regulation of nitrogen fixation genes in Herbaspirillum seropedicae. J Biotechnol 91: 189-195.

Pereira JAR and Baldani JI. 1995. Selection of Azospirillum spp. and Herbaspirillum seropedicae strains to inoculate rice and maize plants. In: INTERNATiOnal Symposium on Sustainable Agriculture FOR the Tropics: the Role Biological NitrogeN Fixation, Angra dos Reis, RJ, Brazil, p. 220-221.

Pereira JAR, Cavalcanti VA, Baldani JI AND DöBeREINER J. 1988. Field inoculation of sorghum and rice with Azopirillum spp and Herbaspirirllum seropedicae. P1 Soil 110: 269-274.
Persuhn DC, Souza EM, Steffens MB, Pedrosa FO, YATES MG AND Rigo LU. 2000. The transcriptional activator NtrC controls the expression and activity of glutamine synthetase in Herbaspirillum seropedicae. FEMS Microbiol Lett 192: 217-221.

Petrini O. 1991. Fungal endophytes of tree leaves. In: Andrews J And Hirano S (Eds), Microbial ecology of leaves. New York: Springer Verlag, p. 179-197.

Pimentel JP, Olivares FL, Pitard RM, Urquiaga S, Akiba F and Dobereiner J. 1991. Dinitrogen fixation and infection of grass leaves by Pseudomonas rubrisubalbicans and Herbaspirillum seropedicae. Pl Soil 137: 61-65.

Polidoro JC. 2001. O molibdênio na nutrição nitrogenada e na fixação biológica de nitrogênio atmosférico associada à cultura da cana-de-açúcar. DSc thesis, Universidade Federal Rural do Rio de Janeiro, RJ, Brasil.

Potrich DP, Bressel TA, Schrank IS and Passaglia LMP. 2001a. Sequencing and promoter analysis of the nifENXorf3orf5fdxAnifQ operon from Azospirillum brasilense Sp7. Braz J Med Biol Res 34: 13651496.

Potrich DP, PASSAglia LMP AND Schrank IS. 2001b. Partial characterization of nif genes from the bacterium Azospirillum amazonense. Braz J Med Biol Res 34: 1105-1113.

Ramos HJO, Roncato-Maccari LDB, Souza EM, SoAres-Ramos JRL, Hungria M ANd Pedrosa FO. 2002. Monitoring Azospirillum wheat interactions using the $g f p$ and $g u s$ A genes constitutively expressed from a new broad-host range vector. J Biotechnol 97: 243-252.

Reinhold B, Hurek T, Fendrik I, Рot B, Gillis M, Kersters K, Thielemans S and De Ley J. 1987. Azospirillum halopraeferens sp. nov. a nitrogenfixing organism associated with roots of Kallar grass (Leptochloa fusca (L.) Kunth). Int J Syst Bacteriol 37: 43-51.

Reis-Jr FB, Silva LG, Reis VM and Döbereiner J. 2000. Ocorrência de bactérias diazotróficas em diferentes genótipos de cana-de-açúcar. Pesq Agropec Bras 35: 985-994.

ReIS VM AND DöBEREINER J. 1998. Effect of high sugar concentrtaion on nitrogenase activity of Acetobacter diazotrophicus. Arch Microbiol 171: 13-18. 
ReIS VM, Olivares FL AND Döbereiner J. 1994. Improved methodology for isolation of Acetobacter diazotrophicus and confirmation of its endophytic habitat. World J Microbiol Biotechnol 10: 401-405.

Reis VM, Olivares FL, Oliveira ALM, Reis Jr FB, Baldani JI AND Döbereiner J. 1999. Technical approaches to inoculate micropropagated sugar cane plants with Acetobacter diazotrophicus. Pl Soil 296: 205-211.

Reis VM, Baldani JI, BALdANi VLD ANd Döbereiner J. 2000. Biological dinitrogen fixation in gramineae and palm tree. Crit Rev Pl Sc 19: 227-247.

ReIS VM ET AL. 2004. Burkholderia tropica sp. nov., a novel nitrogen-fixing plant-associated bacterium. Int J Syst Evolut Microbiol 54: 1-28.

Revers LF, Passaglia LMP, Marchal K, Frazzon J, Blaha CG, Vanderleyden J AND Schrank IS. 2000. Characterization of an Azospirillum brasilense Tn5 mutant with enhanced $\mathrm{N}_{2}$ fixation: the effect of ORF280 on nifH expression. FEMS Microbiol Lett 183: 23-29.

Rodrigues LS, Rodrigues EP, BALDANi VLD AND BALDANI JI. 2001. Estudo da associação de bactérias diazotróficas endofíticas em cultivares de arroz inundado. In: Congresso Brasileiro de MicrobioloGIA, 21, Foz do Iguaçu, PR, Brasil, 272 p.

Rosado AS, Seldin L, Wolters A and van Elsas JD. 1996. Quantitative 16S rDNA-targeted polymerase chain reaction and oligonucleotide hybridization for the detection of Paenibacillus azotofixans in soil and the wheat rhizosphere. FEMS Microb Ecol 19: $153-164$.

Rosado AS, Azevedo FS, Cruz DW, van Elsas JD AND SELDIN L. 1998. Phenotypic and genetic diversity of Paenibacillus azotofixans strains isolated from rhizoplane or rhizosphere soil of different grasses. J Appl Microbiol 84: 216-226.

RusChel AP AND DöBEREINER J. 1965. Bactérias assimbióticas fixadoras de $\mathrm{N}$ na rizosfera de gramíneas forrageiras. In: Congresso InTERnACIONAL de PASTAGENS, 9, São Paulo, SP, Brasil, p. 1103-1107.

Salles JF, Gitahy PM, Skot L and Baldani JI. 2000. Use of endophytic bacteria as a vector to express the cry $3 A$ gene from Bacillus thuringiensis. Braz J Microbiol 31: 155-161.

Sampaio MJA, Vasconcelos L and Döbereiner J. 1978. Characterization of three groups within Spi- rillum lipoferum Beijerinck. In: Granhall U (Ed), Environmental role of nitrogen-fixing blue green algae and asymbiotic bacteria. Ecological Bulletins, 26, Stockholm: Swedish Natural, p. 364-365.

Santos PEL, Bustillos-Cristalles R and CABalLero-Mellado J. 2001. Burkholderia, a genus rich in plant-associated nitrogen-fixers with wide environmental and geographic distribution. Appl Environ Microbiol 67: 2790-2798.

SAntos ST, SAntos AM, Reis VM, Teixeira KRS And BALDANI JI. 1999. PCR/RFLP analysis of Acetobacter diazotrophicus strains isolated from sugarcane genotypes originated from different countries. In: INTERNATIONAL CONGRESS ON NitrogEn FiXATION, 12, Foz de Iguaçu, PR, Brazil, 611 p.

Schrank IS, Zaha A, Araújo EF and Santos DS. 1987. Construction of a gene library from Azospirillum brasilense and characterization of a recombinant containing the nif structural genes. Braz J Med Biol Res 20: 321-330.

Scott DB, Scott CA And DöBereiner J. 1979. Nitrogenase activity and nitrate respiration in Azospirillum spp. Arch Microbiol 121: 141-145.

Seldin L, van Elsas JD and Penido EGC. 1984. Bacillus azotofixans sp. nov., a nitrogen-fixing species from Brazilian soils and roots. Int J Syst Bacteriol 34: 451-456.

Seldin L, Rosado AS, Cruz DW, Nobrega A, van Elsas JD and Paiva E. 1998. Comparison of Paenibacillus azotofixans strains isolated from rhizoplane, rhizosphere and non-rhizosphere soil from maize planted in two different Brazilian soils. Appl Environ Microbiol 64: 3860-3868.

Sevilla M, Meletzus D, Teixeira KRS, Lee S, Nutakki A, Baldani JI ANd Kennedy C. 1997. Analysis of nif and regulatory genes in Acetobacter diazotrophicus. Soil Biol Biochem 29: 871-874.

Sevilla M, Burris RH, Guanapala N and Kennedy C. 2001. Comparison of benefit to sugarcane plant growth and ${ }^{15} \mathrm{~N}_{2}$ incorporation following inoculation of sterile plants with Acetobacter diazotrophicus wild type and nif-mutant strains. Mol Plant-Microbe Interact 14: $358-366$.

Silva LG, Miguens FC and Olivares FL. 2003. Herbaspirillum seropedicae and sugarcane endophytic interaction investigated by using high pressure freez- 
ing electron microscopy. Braz J Microbiol 34: 6971.

Silva LG, Ferreira FP, Marques Júnior RB. 2004. Ultrastructural aspects of Gluconacetobacter diazotrophicus, Herbaspirillum spp. and sugarcane relantionships: a cryotechnique approach. In: LATINAmerican Conference on Rhizobiology, 22, Brazilian Conference on Biological Nitrogen Fixation, 1, Miguel Pereira, RJ, Brazil, 25 p.

Silva RA, Olivares FL and Baldani VLD. 2000. Caracterização anatômica da interação endofítica entre bactérias das espécies Herbaspirillum seropedicae e Burkholderia brasilensis em plântulas de arroz (Oryza sativa). In: Reunião Brasileira de FERTILidade do Solo E Nutrição das Plantas, 24, ReUNião Brasileira Sobre Micorrizas, 8, Simpósio Brasileiro de Microbiologia do Solo, 6, ReuNĩ̃o Brasileira de Biologia do Solo, 3, Santa Maria, RS, Brasil, 173 p.

Souto SM AND DöBereiner J. 1967. Fixação de nitrogênio atmosférico por Beijerinckia na rizosfera do capim elefante (Pennisetum purpureum) "elefante de pinda". In: Congresso Brasileiro DE CiÊNCIA DO Solo, 11, Brasília, DF, Brasil, p. 32-34.

Souto SM AND DöBereiner J. 1984. Metodologia para medição da fixação biológica de nitrogênio em raízes de gramíneas forrageiras tropicais. Pesq Agropec Bras 19: 553-565.

Souza EM, Funayama S, Rigo LU and Pedrosa FO. 1991a. Cloning and characterization of the nifA from Herbaspirillum seropedicae strain Z78. Can J Microbiol 37: 425-429.

Souza EM, Funayama S, Rigo LU, Yates MG and Pedrosa FO. 1991b. Sequence and structural organization of a nifA-like gene and part of a nifB-like gene of Herbaspirillum seropedicae strain Z78. J Gen Microbiol 137: 1511-1522.

Souza EM, Pedrosa FO, Drummond M, Rigo LU AND YATES G. 1999. Control of Herbaspirillum seropedicae NifA activity by ammonium ions and oxygen. J Bacteriol 181: 681-684.

Souza EM, Pedrosa FO, Rigo LU, Machado HB and YATES MG. 2000. Expression of the nifA gene of Herbaspirillum seropedicae: role of $\mathrm{NtrC}$ and NifA binding-sites and of -24/-12 promoter element. Microbiology 146: 1407-1418.
Steenhoudt O And Vanderleyden J. 2000. Azospirillum, a free-living nitrogen-fixing bacterium closely associated with grasses: genetic, biochemical and ecological aspects. FEMS Microbiol Rev 24: 487506.

Steffens MB, Rigo LU, Funayama S, Souza EM, Machado HB and Pedrosa FO. 1993. Cloning of a recA-like gene from the diazotroph Herbaspirillum seropedicae strain Z78. Can J Microbiol 39: 1096-1102.

Stephan MP, Pedrosa FO and Döbereiner J. 1981. Physiological studies with Azospirillum spp. In: Vose PB And Ruschel AP (Eds), Associative $\mathrm{N}_{2}$ fixation. Boca Raton: CRC, p. 7-13.

Stephan MP, Oliveira M, Texeira KRS, MartinezDrets G And DöBereiner J. 1991. Physiology and dinitrogen fixation of Acetobacter diazotrophicus. FEMS Microbiol Lett 77: 67-72.

STONE JK. 1986. Foliar endophytes of Pseudotsuga menziesli (Mirb) Franco. Cytology and physiology of the host-endophyte relationship. DSc Thesis, University of Oregon, Eugene, Canada.

TAPia - Hernandez A, Bustilios-Cristales Mr, JimeneZ-SAlgado T, CABAllero-Mellado J AND FuENTES-RAmíREZ LE. 2000. Natural endophytic occurrence of Acetobacter diazotrophicus in pineapple plants. Microbial Ecol 39: 49-55.

TARRAnd JJ, KRIEg NR AND Döbereiner J. 1978. A taxonomic study of the Spirillum lipoferum group, with the descriptions of a new genus, Azospirillum gen. nov. and two species Azospirillum lipoferum (Beijerinck) comb. nov. and Azospirillum brasilense sp. nov. Can J Microbiol 24: 967-980.

Teixeira KRS, Stephan MP ANd Döbereiner J. 1987. Physiological studies of Sacarobacter nitrocaptans, a new acid tolerant $\mathrm{N}_{2}$-fixing bacterium. In: INternational Symposium on Nitrogen Fixation WITH NON-Legumes, 4, Rio de Janeiro, RJ, Brazil, $149 \mathrm{p}$.

Teixeira KRS, Wulling M, Morgan T, Galler R, Zellerman EM, Baldani JI, Kennedy C and Meletzus D. 1999. Molecular analysis of the chromosomal region encoding the nifA and nifB genes of Acetobacter diazotrophicus. FEMS Microbiol Lett 71: 521-530.

Thompson JP AND Skerman VBD. 1981. Azorhizophilus paspali, comb. nov. invalidation of the pub- 
lication of new names and new combinations previously effectively published outside the IJSB n.6. Int J Syst Bacteriol 31: 215-218.

Tran Van V, Berge O, Ngô Kê S, Balandreau J and Heulin T. 2000. Repeated beneficial effects of rice inoculation with a strain of Burkholderia vietnamiensis on early and late yield components in low fertility sulphate acid soils of Vietnam. Pl Soil 218: 273-284.

Vande Broek A and Vanderleyden J. 1995. The genetics of the Azospirillum-plant root association. Crit Rev Plant Sci 14: 445-466.

Vargas C, de Pádua V, Nogueira EM, Vinagre F, Masuda HP, da Silva FR, Baldani Ji, Ferreira PCG AND Hemerly AS. 2003. Signaling pathways mediating the association between sugarcane and endophytic diazotrophic bacteria: a genomic approach. Symbiosis 35: 159-180.

Vitorino JC, Steffens MBR, Machado HB, Yates MG, Souza EM and Pedrosa FO. 2001. Potential roles for the $g \ln B$ and $n t r Y X$ genes in Azospirillum brasilense. FEMS Microbiol Lett 201: 199-204.

Volpon AGT, De-Polli H ANd Döbereiner J. 1981. Physiology of nitrogen fixation in Azospirillum lipoferum BR 17 (ATCC 29709). Arch Microbiol 128: 371-375.

Von Bülow J AND DöBereiner J. 1975. Potential for nitrogen fixation in maize genotypes in Brazil. Proc Nat Acad Sci USA 72: 2389-2393.

VON DER WeId I, DUARTE GF, van Elsas JD AND SELDIN L. 2002. Paenibacillus brasilensis sp. nov., a new nitrogen-fixing species isolated from the maize rhizosphere in Brazil. Int J Syst Evolut Microbiol 52: 2147-2153.
Wassem R, Souza EM, Yates G, Pedrosa FO and Buck M. 2000. Two roles for integration host factor at an enhancer-dependent nifA promoter. Mol Microbiol 35: 756-764.

Wassem R, Pedrosa FO, Yates MG, Rego FGM, ChuBatsu LS, Rigo LU and Souza EM. 2002. Control of antogenous activation of Herbaspirillum seropedicae nifA promoter by the IHF protein. FEMS Microbiol Lett 212: 177-182.

Weber OB, Baldani VLD, Teixeira KRS, Kirchhof G, BALdANi JI AND DöBEREINER J. 1999. Isolation and characterization of diazotrophic bacteria from banana and pineapple plants. Pl Soil 210: 103-113.

Yabuuchi E, Kosako Y, Oyaizu H, Yano I, Hotta H, Hashimoto Y, Ezaki T and Arakawa M. 1992. Proposal of Burkholderia gen. nov. and transfer of seven species of the genus Pseudomonas homology group II to the new genus, with the type species Burkolderia cepacea (Palleroni and Holmes, 1981) comb. nov. Microbiol Immunol 36: 1251-1275.

Yamada Y, Hoshino K and Ishikawa T. 1997. The phylogeny of acetic acid bacteria based on the partial sequences of $16 \mathrm{~S}$ ribossomal RNA: the elevation of the subgenus Gluconoacetobacter to generic level. Biosc Biotechnol Biochem 61: 1244-1251.

Yamada Y, Hoshino K and IshiKawa T. 1998. Validation list nr. 64. Int J Syst Bacteriol 48: 327-328.

Zhang H, Hanada S, Shigematsu T, Shibuya K, Kamagata Y, Kanagawa T and Kurane R. 2000. Burkholderia kururiensis sp. nov., a tricloroethylene (TCE)-degrading bacterium isolated from an aquifer polluted with TCE. Int J Syst Evolut Microbiol 50: 743-749. 